Maurice A. Deane School of Law at Hofstra University Scholarly Commons at Hofstra Law

Hofstra Law Faculty Scholarship

2002

\title{
E-Buyer Beware: Why Online Auction Fraud Should Be Regulated
}

Miriam R. Albert

Maurice A. Deane School of Law at Hofstra University

Follow this and additional works at: https://scholarlycommons.law.hofstra.edu/faculty_scholarship

\section{Recommended Citation}

Miriam R. Albert, E-Buyer Beware: Why Online Auction Fraud Should Be Regulated, 39 American Bus. L.J. 575 (2002)

Available at: https://scholarlycommons.law.hofstra.edu/faculty_scholarship/423

This Article is brought to you for free and open access by Scholarly Commons at Hofstra Law. It has been accepted for inclusion in Hofstra Law Faculty Scholarship by an authorized administrator of Scholarly Commons at Hofstra Law. For more information, please contact lawcls@hofstra.edu. 


\title{
E-BUYER BEWARE: WHY ONLINE AUCTION FRAUD SHOULD BE REGULATED
}

\author{
Miriam R. Albert*
}

INTRODUCTION

Well-settled principles of law, such as those encompassing fraud in its various forms, have long maintained their vitality, adapting to changes in the legal and business environments through judicial and legislative interpretation and intervention. Many of these changes have manifested themselves in the world of commerce. The creation and development of the Internet has resulted in significant changes in the way people engage in commerce. The increasing popularity of the Internet as a medium of commerce has generated an increase in Internet fraud, raising new and challenging legal issues in areas including online auctions. Under current law, a defrauded participant in an online auction transaction has no recourse against the online auction site that facilitated and controlled the auction transac-

- Assistant Professor of Legal and Ethical Studies, Fordham University School of Business; LL.M., New York University, 1997; J.D. and MBA, Emory University, 1987; B.A. Tufts University, 1984. The author would like to thank those who provided valuable assistance: Donna Gitter, Lisa Hone and Delores Gardner Thompson of the Federal Trade Commission, Assistant U.S. Attorney Chris Sonderby, and especially Dan Berick. I am also grateful for the generous support of the Fordham University School of Business. 
tion and claimed a percentage of the transaction price as its fee. Online auction sites can and do legally disclaim any responsibility for fraud occurring on their sites. Because of the lack of meaningful consumer protection with respect to online auctions in the form of consumer education efforts and appropriate regulation and effective enforcement thereof, the rising numbers of online auction fraud victims are left with no meaningful avenues of relief.

The Internet has existed, in various forms, since the mid-1960s, beginning as an experiment in computer interface amongst a handful of research institutions and evolving into the fastest-growing electronic communication tool in history, with "the potential to provide more communicative power, purchasing capability, and knowledge gathering outreach than print and electronic media combined." Each year, the number of Internet users increases almost exponentially. ${ }^{2}$ In 1997, an estimated nineteen million Americans were using the Internet. ${ }^{3}$ By 2000 , more than 104 million Americans had access to the Internet. ${ }^{+}$

These Internet users are doing more than checking their email and horoscopes. They are engaging in a phenomenon known as "ecommerce"-creating a global electronic marketplace where they purchase and sell goods and services on the Internet, either directly from sellers' web sites or through communities of sellers associated

${ }^{1}$ UCLA Center for Communication Policy, The LCLA Internet Repont: Sunveying the Digital Future, 4, at http://www.ccp.ucla.edu/LCLA-Intent-Report-2000.pdf (Oct. 25, 2000) [hereinafter The LCLA Intemet Report].

It

"Id: see also Pew Internet and American Life Project, More Online, Doing More, at http://www pewintemetorg/releases/release asp?id=15 (Feb. 18, 2001); Number of Nexo Internet Users is Grozeing, N.Y. TIMLS, Feb. 19, 2001, at C.3.

Internet participants include hosts in addition to users. In 1984, the domain name system was introduced, and the number of hosts exceeded 1,000. By 1992, the number of hosts had exceeded one million, and by 1996, the number of hosts neared ten million. See Life on the Internet: Net Timeline, at http://www.pbs.org/internet/timeline/timeline-txt.html last visited Mar. 9, 2002).

"See Prepared Statement of the Federal Trade Commission on "Internet Fraud" Before the Subcommittee on Commerce, Trade, and Consumer Protection of the Committee on Energy and Commerce, 107th Cong. 2 2001) istatement of Eileen Harrington, Associate Director of the Division of Marketing Practices in the Federal Trade Commission's Bureau of Consumer Protection), available at http://www.ftc.gov/os/2001/05/internetfraudtmy.htm last visited Mar, 9, 2002) [hereinafter FTC Statement on Intemet Fraud]. 
through online auction sites. ${ }^{5}$ This global electronic marketplace has grown rapidly, and that pace of growth is expected to continue, ${ }^{6}$ rising from an estimated $\$ 2.6$ billion in 1996 to an estimated $\$ 220$ billion by the end of 2001..$^{7}$ Analysts predict that by the year 2002, e-commerce will account for more than $\$ 300$ billion of the U.S. gross national product. ${ }^{8}$ Global e-commerce revenue is estimated to reach $\$ 3.2$ trillion by 2003 , constituting almost five percent of all global sales. ${ }^{9}$

One form of e-commerce, the online auction, has become increasingly popular since it first appeared in $1995 .^{10}$ Over 1.3 million transactions per day take place on online auction sites. ${ }^{\text {" }}$ The number of online auction participants was projected to be 6.5 million

${ }^{5}$ More than half $(50.7 \%)$ of Internet users have made a purchase online. See UCLA Internet Report, supra note 1, at 10 . Just $4.5 \%$ of all Internet users are responsible for $31.4 \%$ of all online purchases. $8.9 \%$ of purchasers buy online weekly, while $28.5 \%$ buy online monthly. The average amount spent online per month by Internet buyers is $\$ 13$ with $3.5 \%$ of users spending more than $\$ 500$ per month online. Id. at 41,46 ; see also Consumer Protection in Cyberspace: Combating Fraud on the Internet: Before the Telecommunications, Trade, and Consumer Protection Subcommittee of the House Comm. on Commerce, 105th Cong. 3 (1998) (statement of Eileen Harrington, Associate Director of the Division of Marketing Practices in the Federal Trade Commission's Bureau of Consumer Protection), available at http://www.ftc.gov/os/ 1998/9806/test.623.htm (last visited Mar. 9, 2002) [hereinafter FTC Statement on Consumer Protection].

${ }^{6}$ See Thomas J. Smedinghoff \& Ruth Hill Bro, Moving with Change: Electronic Signature Legislation as a Vehicle for Advancing e-commerce, 17 J. MARSHALLJ. COMPLTER \& INFO. L. 723, 725 (1999); see also James M. Snyder, Online Auction Fraud: Are the Auction Houses Doing All They Should or Could to Stop Online Fraud?, 52 FED. CoMM. L.J. 453, 456 (2000); FTC Chairman Robert Pitofsky's Opening Remarks at Workshop on Consumer Protection in the Global Electronic Market 1, available at http://www.ftc.gov/opa/1999/9906/globalpitof.htm (June 8, 1999).

${ }^{7}$ See FTC Statement on Consumer Protection, supra note 5, at 3; see also Fraud Could Slow Growth of Electronic Commerce: FTC, 1, available at http://www.ftc.gov/opa/1998/9806/ehpress.htm (June 25, 1998).

"See The Law of Cyberspace, 112 HARV. L. RFV. 1574, 1577 (1999).

${ }^{9}$ See Linda Himelstein et al., Why They're Nuts About the Net, BUS. WK., Nov. 23, 1998, at 52 (citing market research firm Jupiter Communications).

${ }^{10}$ See Internet Auctions: A Guide For Buyers and Sellers 1, available at http://www/ftc.gov/bcp/ conline/pubs/online/auctions. htm (last visited Mar. 9, 2002) [hereinafter Internet Auctions: $A$ Guide].

11 See Internet Auction Fraud 4, 13, available at http://www.ifccfbi.gov/strategy/Auction FraudReport.pdf (May 2001) [hereinafter Intermet Auction Fraud Report]. 
by the end of $2000 .{ }^{12}$ As of January 2001, that projection was dramatically exceeded, with 35 million people participating in online auctions. ${ }^{13}$ Online auctions constitute a $\$ 6.4$ billion per year industry, with that figure estimated to increase to $\$ 15.1$ billion per year by $2004 .^{14}$ As the number of online auction participants rises, the potential for, and number of, online auction complaints rises as well. ${ }^{15}$

The increased popularity of the Internet and the huge volume of e-commerce transactions have generated opportunities for cyber crimes and torts, including various forms of Internet fraud. ${ }^{16}$ The

1.2 See John Hendren, Fraud Can Taint Online Auctions, Beffalo News, Feb. 9, 1999, at 8E (citing market research firm Jupiter Communications). This trend in online auction participation is not limited to the United States. See Mike Anderiesz, Go Where the Auction Is, Scotsmax, Oct. 4, 1999, at 22; see also Judith H. Dobrzynski, The Bidding Game: $A$ Special Repont; In Online Auction World, Hoaxes Aren't Easy to See, N.Y. TIMES, June 2, 2000, at A1 (citing market research firm Jupiter Communications) [hereinafter The Bidding Game]. However, differences in the various countries' laws make a comprehensive analysis of online fraud on a global basis beyond the scope of this article. See generally America Online's Response to the Federal Trade Commission's Request for Academic Papers and Public Comments 1, available at http://www.ftc. gov/bcp/icpw/comments/aol.htm (Mar. 26, 1999).

$1: 3$ See Online Auction Surey Summary, at http://www.nclnet.org/online auctions/auction survey2001.htm (Jan. 31, 2001).

1t See Marty Jerome, Bidder Beware Online, Bostoy Globr, July 9, 2000, at J35 (citing market research firm Jupiter Communications); see also Jim Carlton \& Pui-wing Tam, Online Auctioneers Face Growing Fraud Problem, WAL.L.ST.J., May 12, 2000, at B6 (quoting Paul Luehr, an assistant director at the Federal Trade Commission).

${ }_{15}$ See Hendren, supra note 12; see also infra notes 36-47 and accompanying text; Tom Holland, Eliminating Online Auction Fraud at http://www.auctionwatch.com/awdaily/view point/speakout/amazon-fraud.html (Aug. 30, 1999).

${ }^{16}$ See FTC Statement on Internet Fraud, supra note 4, at 2; see also Revolution in Internet Commetce is "Profoundly Pro-Consumer" Pitofsky Says 1, at http://www.ftc.gov/opa/2000/02/wilson.htm (last visited Mar. 9, 2002). According to the Department of Justice:

In general, the same type of fraud schemes that have victimized consumers and investors for many years before the creation of the Internet are now appearing online (sometimes with particular refinements that are unique to Internet technology.) With the explosive growth of the Internet, and e-commerce in particular, online criminals try to present fraudulent schemes in ways that look, as much as possible, like the goods and services that the vast majority of legitimate e-commerce merchants offer. In the process, they not only cause harm to consumers and investors, but also undermine consumer confidence in legitimate e-commerce and the Internet.

Internet Fraud, at 3, available at http://www.usdoj.gov/criminal/fraud/Internet.htm (last visited Mar. 9, 2002) [hereinafter Intemet Fraud]; see also Carlton \& Tam, supra note 14; Jerome, supra note 14. Some of these schemes are simply variations on age-old scams, just relocated to cyberspace. Others are newly created for, and could only exist in, cyberspace. See Tony Wanless, Age-Old Scams Thrive Online: the Internet is Hauling in the Suckers and Fraud is 
Internet offers low-cost communication, the capacity to reach a global audience, and a presumptive veneer of credibility stemming from the anonymity of cyberspace. ${ }^{17}$ Thus, Internet users may find it hard to distinguish genuine sources of information from fraudulent sources, creating a fertile environment for all kinds of Internet fraud. ${ }^{18}$ "Internet fraud" is a broad term, referring generally to any kind of fraud scheme using a component of the Internet, be it chat rooms, email, message boards, or Web sites, to "present fraudulent solicitations to prospective victims, to conduct fraudulent transactions, or to transmit the proceeds of fraud to financial institutions or to other [s] connected with the scheme."19 Other common forms of Internet fraud include online retail schemes, online business opportunity/ "work at home" schemes, online identity theft and fraud, online market manipulation schemes, and online auction fraud. ${ }^{20}$

This article examines the most commonly reported form of Internet fraud, online auction fraud. ${ }^{21}$ Part I discusses fraud in the context of online auctions, highlighting the increasing numbers of

Hard to Prove, GazeTTE, Dec. 4, 2000, at F3; see also Alan L. Zegas, Cybercrime's Many Faces, N.J. L.J., May I, 2000, at 24; About Internet Fraud Watch, at http://www.fraud.org/internet/ intinfo.htm (last visited Mar. 9, 2002).

${ }^{17}$ See Report from the National Consumers League to the U.S. Department of Justice Conceming Telemarketing and Intemet Fraud 2, available at http://www.fraud.org/telemarketing/ fraudrep.htm (Jan. 10, 2000) [hereinafter NCL Report]; see also Christian Berthelsen, Online Crime is Easy, But Often Easier to Crack, SAN DiEgo Union-Trib., Sept. 26, 2000, at 4; Jonathan J. Rusch, Don't Look Now, 9 GkO. MASON L. REV. 289, 314 (2000).

${ }_{18}$ See Internet Fraud, supra note 16, at 2; Snyder, supra note 6, at 465.

${ }^{19}$ Internet Fraud, supra note 16, at 19; see also On-Line Fraud and Crime: Are Consumers Safe? Hearings Before the House Subcomm. on Commerce, Trade and Consumer Protection 107th Cong. (2001), available at http://www.nclnet.org/susantestimony52301.html (last visited Mar. 9, 2002) (testimony of Susan Grant, Director of the Internet Fraud Watch, Vice President, Public Policy, National Consumers League). The Federal Trade Commission created a list of the top ten Internet frauds of 1998, characterized as "dot-cons," some of which are as old as fraud itself, including: online auction transactions, general merchandise sales, computer hardware/software sales, Internet-related services, work-at-home plans, business opportunities/franchises, multi-level marketing/pyramid schemes, credit card offers and advance fee loans, and job listing/employment offers. See NCL Report, supra note 17, at 2; see also Online Traps for the Unwary, DENVER ROCKy MT. NEws, Nov. 11, 2000, at 60A.

${ }^{20}$ See Intermet Fraud, supra note 16, at 3. The term "Internet fraud" is broad enough to include forms of fraud that are more of an administrative issue for online auction sites, such as fraud in the bidding process. See infra notes 53-59 and accompanying text.

2) A detailed discussion of the other forms of Internet fraud is beyond the scope of this article. 
reported cases and the most common forms of online auction fraud. Part II examines two prominent online auction fraud cases, and illustrates the critical need both to protect consumers from being victimized by online auction fraud and to provide opportunities for meaningful relief in the event that consumers are so victimized. Part III offers suggested areas for regulation to protect consumers from online auction fraud, and further provides an examination and evaluation of the responses to online auction fraud by various consumer and law enforcement groups. Part IV examines the response of online auction sites to online auction fraud..$^{22}$ Part $\mathrm{V}$ is an

2 eBay.com is the undisputed giant of the online auction world. As a result, much of the analysis in this article uses $\mathrm{eBay}$ as the industry standard and representative of all other online auction sites. To the extent any particular online auction site differs from eBay in any relevant respect, such differences are pointed out.

eBay is so dominant as to make it the defining voice on policies and procedures among online auction sites. In fact, according to eBay, many of its competitors use its policies and procedures, as well as its documentation, on their own rival sites, sometimes right down to the typographical crrors. See David Streitfeld, Ex-prosecutor Polices eBay, CHI. SL N-TIMEs, Dec. 14, 1999, at 46 :quoting Robert Chestnut, Associate General Counsel for eBay).

Founder Pierre Omidyar created eBay in 1995 as a vehicle to sell his then-girlfriend's Pez dispensers. See Hendren, supra note 12. eBay now has over ninety percent of the online auction market, dwarfing its closest rivals Yahoo! and Amazon.com. See The Bidding Game, supra note 12.

According to Media Metrix, a firm that measures Internet usage, eBay began 2000 as the Intemet's number-one shopping site; $\mathrm{eBay}$ 's average daily reach (defined as the percent of all Internet users; exceeded $6.5 \%$, beating the second most popular site by fifty-eight percent. See Robert Scally, The Auction Netzerk Making a Bid for On-Line Dominance, DSN RETALIV; TODAY at hitp://www.findarticles.com/cf_0/m0FNP/9_39/63800035/ print.jhtml May 8, 2000 ion fle with author. On a typical day, 1.8 million visitors enter

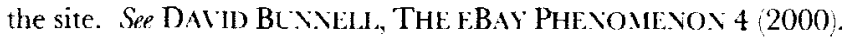

eBay, the self-proclaimed "world's largcst personal online trading community" has over 8,000 categories of items up for auction, with 34.1 million registered users. In 2000, eBay's annualized gross merchandise sales the value of goods traded on the site) exceeded $\$ 5$ billion. See About eBay: Compan) Oceniew: Index, at http://pages.ebay.com/community/ aboutebay/overview/index.html last visited Mar. 9, 2002; see also Adam Cohen, eBay's Bid to Conquer All, Time, Feb. 5, 2001, at 48; The Standard: eBay, Inc., at http://www.the standard.com/companies/dussier/0,1922,280819.hml last visited Mar. 9, 2002); Michelle Demely, Record Ramues for eBay, at http://www.auctionwatch.com/email/print.html?ret= /awdaily/dailynews/july01/1-07190l.html July 19, 2000). Unlike many Internet enterprises, eBay continues to grow and succeed, actually making money. For the year ending Dccember 31, 1999, eBay's net revenues were $\$ 224.7$ million, up $161 \%$ from net revenues of $\$ 86.1$ million for fiscal year 1998 . Net income for 1999 was $\$ 10.8$ million, or 8 cents per share on a diluted basis. See Scally, supra. For the year ending December 31 , 
examination of some forms of online alternative dispute resolution. Because of the lack of meaningful consumer protection stemming from the lack of appropriate regulation and effective enforcement thereof, and the dearth of consumer education with respect to online auction fraud, online alternative dispute resolution remains one of the only available avenues of relief for victims of online auction fraud.

\section{FRAUD IN THE AGE OF THE INTERNET}

Fraud is one of the oldest causes of action in American jurisprudence. ${ }^{23}$ The term "fraud" is a generic term describing any of the variety of ways a party can lie or suppress the truth for personal gain. ${ }^{24}$ In general, a successful plaintiff must show the defendant's misrepresentation of a past or present material fact. The defendant must be shown to have had scienter and the intent to induce reliance by the plaintiff. Further, the plaintiff must demonstrate her justifiable reliance on the misrepresentation. ${ }^{25}$ Fraud includes claims of fraudulent inducement, when a party is enticed into the contract through misrepresentation or fraud, as well as fraud in the factum, when the fraud occurs during the process of obtaining execution or delivery. ${ }^{26}$

\section{A. Online Auction Fraud in General}

The application of the principles of fraud in the context of the Internet poses complicated and important issues. Internet fraud has particular resonance in the context of online auctions, with fraud occurring both during the bidding process and after the bidding

2000 , eBay's net revenues were $\$ 430$ million, up $92 \%$ over fiscal year 1999 . See Cohen, supra. For the third quarter of 2001 , eBay had net revenue of $\$ 194.4$ million, a $71 \%$ increase over the $\$ 113.4$ million it earned in the same quarter of 2000 . eBay's net income for the quarter was $\$ 18.8$ million. See eBay, Inc. Quarterly Financials-Hoover's Online, at http://www. hoovers.com/quarterlies/7/0,2167,56307,00.html (last visited Mar. 9, 2002).

${ }^{23} \mathrm{Se} 1$ WARRENFREEDMAN, THE BUSINESS TORT OF FrAUD AND MISREPRESENTATION iii (1989).

${ }^{24}$ The common law fails to define fraud, with the prevailing wisdom holding that fraud would be better left undefined. See id. at 1 (quoting Professor Melville Bigelow); see also 37 C.J.S. Fraud $\$ 2$ (1997).

${ }_{25}$ See Dan B. DobBS, Thf LAW OF TorTs $\S 470$ (2000); see also 37 C.J.S. Fraud $\S 7$ (1997).

${ }^{26}$ See 37 AM. JUR. 2D Fraud and Deceit $\S 2$ (2001). 
process has been completed. ${ }^{27}$ Online auction sites provide a venue for sellers to conduct auctions of goods. ${ }^{28}$ There are considerable differences in the means and volume of online auctions as opposed to traditional auctions. ${ }^{29}$ Unlike traditional auctions, where the parties or their representatives are in the room with the offered merchandise, online auction sites use the Internet to conduct a virtual auction where the parties never meet and the buyer has no opportunity to examine the offered goods. ${ }^{30}$ Further, the volume of online auctions is many times greater than that of traditional auctions. ${ }^{31}$ Unlike traditional auction houses, the online auction sites do not take title to or handle the goods bought or sold using the medium of the

${ }_{27}$ See Intermet Fraud, supra note 16; see also NCL Report, supra note 17, at 2; infra notes 53-59 and accompanying text.

${ }^{28}$ See eBay's Response to the Federal Trade Commission's Request for Academic Papers and Public Comments 3, anailable at http://www.ftc.gov/bcp/icpw/comments/ebay.htm (Mar. 26, 1999) [hereinafter eBay's Response to the FTC].

Interuet auctions are bazaars. In most cases, sellers offer one item at a time, but sometimes sellers offer multiple lots of the same item. The auction web sites often refer to auctions of multiple items as "Dutch" or "English" auctions. At some sites, the seller may be required to sell all items at the price of the lowest successful bid. At other sites, the seller is entitled to the prices bid by each of the highest bidders.

Occasionally, Internet auction sellers set a "reserve price," which is the lowest price they will accept for an item. Some sites disclose the reserve price during the auction. The bidding for each auction closes at a scheduled time, when the highest bidder "wins." In the case of the sale of multiple lots, the participants with the highest bids at the close of the auction are obligated to buy the items. If no one bid at or above the reserve price, the auction closes without a "winner." At the close of a successful auction, the buyer and seller communicate - usually by email-to arrange for payment and delivery of goods.

Internet Auctions: $A$ Gitide, supra note 10, at 1.

"2e" See Mary Kay Finn et al., Policies Lnderlying Congressional Approval of Criminal and Civil Immunity for Interactive Computer Senice Providers Lnder Provisions of the Communications Decency Act of 1996 - Should E-Buyers Beware?, 31 U. Tot.. L. RFY. 347, 370 (2000).

${ }^{30}$ In traditional auctions you could meet the buyer and seller and inspect the merchandise. At the very least, you could make sure the merchandise actually existed. In onlinc auctions, however, you don't know who the seller is, where he is, or whether the offered items even exist. And all too often, they do not.

Brian Krebs, FTC Seeks to Stem Online Auction Fraud, NFusBrILS (Feb. 14, 2000) (quoting U.S. Attorney Christopher Paintcr), at http://www.newsbytes.com/cig-bin/.../im.display. printable? client.id=newsbytes\&story.id-14382.

${ }^{31}$ See supra notes 11-14 and accompanying text; see also Finn et al., supra note 29, at 371. 
Internet. $^{32}$ Thus, online auctions have the potential for abuses not likely or, in some cases, even possible, with traditional auctions. ${ }^{33}$ For example, in the typical online auction, the seller is the only participant with access to the offered item. The buyer relies on the seller's written description, and in some cases, on a digital photograph of the offered item. So, an online auction seller could list an item for sale that differs materially from the description provided, or could list an item for sale that does not even exist. Further, as a practical matter, the large numbers of transactions listed with online auction sites as opposed to traditional auction houses necessitates less attention to each transaction by the online auction house. Also, because online auction sites do not take title to the offered items, and under current law have no liability for fraud occurring on their sites, the online auction sites have little incentive to take steps to prevent fraud on their sites. In fact, the online auction sites consistently disclaim any

${ }^{32}$ See eBay's Response to the FTC, supra note 28, at 3. Traditional auction houses like Sotheby's offer a guarantee of the accuracy of its descriptions of offered items, for both its traditional and Internet auctions. The owner of the property transfers it to the auction house to act on the owner's behalf for the sale at auction. See Sothebys.com-Help-Reference, at http://www.sothebys.com/help/ref/ref_liveterms.html (last visited Mar. 9, 2002).

According to Sotheby's website, the auction house "stand[s] by the accuracy of our bold-type description of authorship (see below) of each lot for a period of five years. A buyer who disputes the correctness of our lot description has recourse through a process set forth in each catalogue." Id. The auction house guarantee is not without limits:

In addition to other exclusions described in the catalogue, we cannot guarantee the authorship of paintings, drawings and sculpture created before 1870. There are also other limitations and exceptions to our standard guarantee that apply to particular types of property. If such exceptions apply, they will appear in the catalogue for the sale.

Id.

It should also be noted that traditional auctions are not without treachery. For example, the concept of "shill bidding" was invented to describe conduct involved with offline auctions. See Jeff Faerber, Some Feel Snookered Amid Auction Hurly-Burly, Miami HrRAI.d, Aug. 23, 1999, at 11BM; see also infra notes 56-68 and accompanying text.

${ }_{33}$ One commentator observes:

Consumer auctions on the Web are booming and, as they become more entrenched, they're spawning a variety of dubious practices, from outright scams to the posting of deceptive information. Though many of these tricks are centuries-old, observers say the relative anonymity of online trading environments gives people the latitude to pull off newer scams they couldn't get away with at live auctions.

Faeber, supra note 32. 
"3t eBay's User Agreement contains the terms and conditions applicable to using the site and is rife with disclaimers:

Although we are commonly referred to as an online auction website, it is important to realize that we are not a traditional "auctioneer." Instead, our site acts as a venue to allow anyone to offer, sell, and buy just about anything, at anytime, from anywhere, in a variety of formats, including a fixed price format and at auction-style format commonly referred to as an "online auction." We are not involved in the actual transaction berween buyers and sellers. As a result, we have no control over the quality, safety or legality of the items advertised, the truth or accuracy of the listings, the ability of sellers to sell items or the ability of buyers to buy items. We cannot ensure that a buyer or seller will actually complete a transaction.

¿Bay User Agrement \$ 3.1, at http://pages.ebay.com/help/community/png-user.html (last visited Mar. 9, 2002:-

In addition, the eBay Lser Agreement disclaims any warranties, express or implied, with respect to the site and services:

WE AND OUR SUPPLIERS PROVTDE OUR WEB SITE AND SERVICES "AS IS" AND WITHOUT ANY WARRANTY OR CONDITION, EXPRESS, IMPIIED OR STATUTORY. WE AND OUR SUPPLIERS SPECIFICALLY DISCLAIM ANY IMPLIED WARR.ANTIES OF TITLE, MERCHANTABILITY, FITNESS FOR A PARTICULAR PURPOSE AND NON-INFRINGEMENT. Some states do not allow the disclaimer of implied warranties, so the foregoing disclaimer may not apply to you. This warranty gives you specific legal rights and you may also have other legal rights which vary from state to state.

Id. \$ 11. The eBay Lser Agreement further limits the site's liability:

IN NO EVENT SHALL WE OR OUR SUPPLIERS BE LIABLE FOR LOST PROFITS OR ANY SPECIAL, INCIDENTAL OR GONSEQUENTIAL DAMAGES ARISING OUT OF OR IN CONNECTION WITH OUR SITE, OUR SERVICES OR THIS AGREEMENT (HOWEVER ARISING, INCLUDING NEGLIGENCE.

OUR LIABILITY, AND THE LIABILITY OF OUR SUPPI IERS, 'TO YOU OR ANY THIRD PARTIES IN ANY CIRCUMSTANCE IS LIMITED TO THE GREATER OF A. THE AMOUNT OF FEES YOU PAY TO US IN THE 12 MONTHS PRIOR TO THE ACTION GIVING RISE TO LIABILITY, AND (B)

$\$ 100$. Some States do not allow the limitation of liability, so the foregoing limitation or exclusion may not apply to you.

It. $\$ 12$.

Further, eBay disclaims responsibility for authenticating any party's identity and suggests users consult the "user-initiated feedback system" and to communicate directly with potential trading partners. See infra notes $210-13$ and accompanying text. eBay mentions the availabiliny of third party escrow services or services that provide additional user verification. See eBay L 'ser Agreenent, supra note 34, $\$ 3.2$; see also infra notes $195-200$ and accompanying text.

eBay requires its users to release eBay and all its officers, directors, agents, subsidiaries, and employees from "any claims, demands and damages (actual and consequential) of every 
fraud has, to date, been borne by the defrauded online auction participants, typically the successful bidder, because under current law a fraud action cannot be sustained against an online auction site. The online auction sites consider themselves simply venues where the true parties to a transaction can meet and decide how much risk they want to assume in any given online auction transaction. To date, no court has found otherwise. ${ }^{35}$

\section{B. Escalating Numbers of Online Auction Fraud Cases}

Industry experts predict a veritable explosion of fraud cases as the number of online auction participants continues to increase. ${ }^{36}$ Online auction fraud is already the most frequently reported form of Internet fraud - ten times as common as the second and third most reported

kind and nature, known and unknown, suspected or unsuspected, disclosed or undisclosed, arising out of or in any way connected with such disputes." eBay User Agreement, supra note 34, $\S 3.3$.

${ }^{35}$ See Hendren, supra note 12. eBay recently won a dismissal of a class action suit by purchasers of autographed sports memorabilia later discovered to be fake, who claimed that eBay had a responsibility to "ensure the authenticity of items sold through its Web site." See eBay's Liability is Cleared in Suit, N.Y. TIMEs, Jan. 20, 2001, at G14. According to eBay's Associate General Counsel, Rob Chestnut, the company's role is like that of a newspaper's classified advertising section, that $\mathrm{eBay}$ simply provides a forum. Id. Had the lawsuit been successful, eBay would have been forced to take a more active role in policing its site for fraud. See David Baranowski, Fraud Case Against eBay Proceeds, at http://www.auction watch. com/email/print.html?ret=/awdaily/dailynews/octobe.../2-101600.htm (Oct. 16, 2000) (on file with the author).

${ }^{36}$ See Robin Fields, Some E-Auction Users Get Less Than They Bargain For; Internet: Fraud Has Escalated at Online Bidding Sites, Prompting Law Enforcement and Security Crackdowens, L.A. TIMES, Mar. 16, 2000, at A1; see also NCL Report, supra note 17, at 2. According to Jodie Bernstein, Director of the Federal Trade Commission's Bureau of Consumer Protection:

We know that with the dramatic expansion of e-commerce, Internet auction sites are experiencing amazing growth. We also know that the number of complaints the FTC has received about Internet auctions is exploding - from 107 in 1997 to 10,700 in 1999. We want Internet auction users and the online auction industry to know that the e-con artists who capitalize on them are 'going, going, gone.' We don't intend to let a handful of rogues erode consumer confidence in Internet commerce or Internet auctions.

Lawe Enforcers Target Internet Auction Fraud, at http://www.ftc.gov/opa/2000/02/ internetauctionfraud.htm (Feb. 14, 2000); see also Anderiesz, supra note 12; David Rovella, Justice Department Prepares for a Cyberwar, N.Y. L.J., Mar. 14, 2000, at 5; see also Wanless, supra note 16. 
kinds of Internet fraud combined. ${ }^{37}$ Consumers have a number of venues for reporting Internet fraud. ${ }^{33}$ The primary venues for reporting Internet fraud cases are the National Consumers League initiative called the Internet Fraud Watch (IFW) ${ }^{39}$ and the Federal Trade Commission (FTC). ${ }^{40}$

The IFW was launched in 1996 to help consumers distinguish legitimate promotions from fraudulent promotions, and to serve as a mechanism to route reports of suspected fraud to the appropriate law enforcement agencies. ${ }^{+1}$ Consumer complaints to the IFW increased by $600 \%$ from 1997 to 1998 , with online auctions complaints numbering almost 5500 , or $68 \%$ of all 1998 complaints, up from $26 \%$ for $1997 .{ }^{42}$ Consumers lost more than $\$ 3.2$ million to Internet fraud,

:37 See Fields, supra notc 36; see also Anita Kumar, Online Auction Scams Multiply, ST. PETIRSBL RG; TIMES, July 17, 2000, at 1B; NCL Report, supra note 17, at 2.

The next most popular type of Internet complaint reported to the Federal Trade Commission involves disagreements over the rights to domain names - a part of an Internet address. The Internet Corporation for Assigned Names and Numbers (ICANN) is a nonprofit corporation set up by the federal government to oversee the distribution of these domain names. IC.ANN adopted a uniform set of policies to govern all domain name dispute resolutions; these policies, the Uniform Domain Name Dispute Resolution Policy and its accompanying rules, became effective in October 1999. See Uniform Domain Dispute Resolution Policy, at http://www.icann.org/udrp/udrp-policy-24oct99.htm (last visited Mar. 9, 2002)

${ }^{33}$ A search of the Internet for the term "Internet fraud" using two of the major search engines, Google.com and Yahoo.com., generated, in the first page of results, links to the National Fraud Information Center, Internet Fraud Watch, and the Internet Fraud Complaint Center, all sites where consumers can report Internet fraud. See http://search.yahoo.com/bin/search?p=internet +fraud (last visited Mar. 9, 2002) (on file with author; see also http://google.com/search?q=internet +fraud\&btnG=Google+search (last visited Mar. 9, 2002) (on file with authori.

3: The National Consumers League created the IFW to opcrate in tandem with its National Fraud Information Center NFIC). See About Internet Fraud Watch, supra note 16; see also infra notes $147-49$.

40) See http://www.ftc.gov (last visited Mar. 9, 2002); see also Snyder, supra note 6, at 454. In addition, the NFIC web site has links to governmental sites and states attorneys general to report incidents of fraud. See Contacting the National Fraud Information Center, at http://www.fraud.org/info/contactnfic.htm last visited Mar. 9, 2002).

${ }^{11}$ See Berthelsen, supra note 17; see also National Consumers League Warns Consumers Millions Are Lost to Intemet Fraud, at http://www.fraud.org/internet/99final.htm (Feb. 16, 2000) [hereinafter NCL Wams Consumers].

${ }^{12}$ The increase in the number of complaints can be attributed to several factors. As the number of Web sites devoted to online auctions increases, it is predictable that the number of frauds occurring on those Web sites will likewise increase. Currently, well over one hundred online auction sites are dedicated to bringing together consumers 
based on incident reports filed with IFW in 1999. ${ }^{43}$ As of October $1999,90 \%$ of consumer complaints to the IFW pertained to online auctions. ${ }^{44}$

The FTC acts as a clearinghouse for Internet fraud complaints, using its Consumer Sentinel program to collect complaints from over 300 law enforcement agencies and consumer groups, including IFW. ${ }^{45}$ The FTC has also seen an increase in online auction complaints from 106 in 1997 to 10,872 in 2000, exceeding even the rapid growth of the online auctions themselves. ${ }^{46}$ For the first quarter of 2001, the FTC received 1,442 online auction complaints. ${ }^{47}$

These numbers may be understating the extent of the problem. Many victims of online auction fraud do not file complaints. ${ }^{48}$ In addition, these figures do not take into account any complaints filed

with other consumers as well as businesses with consumers.

Snyder, supra note 6, at 455-6; see also Fed. Trade Comm'n 1, Going, Going, Gone... Law Enforcement Efforts to Combat Internet Auction Fraud, at http://www.ftc.gov/bcp/reports/intauction.htm (Feb. 2000) [hereinafter Going, Going, Gone]; Anderiesz, supra note 12; NCL Repont, supra note 17 , at 3 .

${ }^{43}$ See NCL Wams Consumers, supra note 41.

${ }^{44}$ See Elizabeth Weise, Tip: Protect Yourself Before Paying For Items, U.S.A. TODAY, Mar. 10, 1999, at 2A; see also Going Once, Going Twice... Scammed! Online Auctions Named the Number One Internet Fraud Complaint for 1998, at http://www.fraud/org/internet/9923stat.htm (Feb. 23, 1999) [hereinafter Going Once, Going Twice].

${ }^{45}$ The NFIC forwards complaints it receives on its site and the IFW site to the FTC's Consumer Sentinel program. See Consumer Sentinel Members, at http://www.consumer.gov/ sentinel/members.htm (last visited Mar. 9, 2002); see also infra notes 86-87 and accompanying text.

${ }^{40}$ See Internet Auction Complaints by Calendar Year from 1997 to 2001 (June 15, 2001) [hereinafter Intemet Auction Complaints] (on file with the author). The number of complaints filed with the FTC actually decreased from 13,901 in 1999 to 10,872 in 2000. The total number of complaints for 2000 is still alarmingly large in absolute terms, and as a percentage of all Internet fraud complaints. Delores Gardner Thompson of the FTC attributes the reduction to several factors including better-informed participants and efforts by law enforcement and by some online auction sites. Of course, defrauded consumers beyond the 10,872 may be filing their complaints with entities other than the FTC, perhaps at the state or local level. See Andy Roe, Online Auction Fraud Declines, at http://www.auctionwatch. com/email/print.html?ret=/awdaily/dailynews/april01/1-041701.html (Apr. 17, 2001).

${ }^{47}$ See Intemet Auction Complaints, supra note 46.

${ }^{48}$ See Intemet Auction Fraud Report, supra note 11, at 5; see also The Internet Fraud Complaint Center Six-Month Data Trends Report: May 8-November 8, 2000, at 3, at http://www.ifccfbi.gov/ strategy/6monthreport.pdf (last visited Mar. 9, 2002) [hereinafter Trends Report]. 
at the state or local level. ${ }^{49}$ The average consumer loss in an online auction transaction in 2000 was approximately $\$ 478,{ }^{50}$ a figure so small that it may have discouraged defrauded participants from pursuing any action, however limited, which gives fraud investigators limited incentive to expend significant resources on any particular case. ${ }^{51}$ Few people will undertake a formal recovery process if the cost of recovery exceeds the cost of the fraud. ${ }^{52}$

\section{Common Forms of Online Auction Fraud}

The increasingly pervasive problem of online auction fraud has several common manifestations. The abuses arise during two separate phases of the online auction process: during the bidding process and after the bidding process has been completed.

During the bidding process, perpetrators can engage in "bid shielding" and "shill bidding." Bid shielding refers to the collusion of bidders to artificially inflate the bids during an auction. One coconspirator puts in a low bid and then another co-conspirator puts in a bid high enough to discourage outside bidders from entering the auction. ${ }^{53}$ Just before the auction closes, the high bid is withdrawn, and the low bidder, by default, is the successful bidder. ${ }^{54}$ Modifications to the way online auction sites conduct their auctions have decreased the potential for bid shielding. Bidders are typically not permitted to withdraw their bids unless there is a typographical error, the seller has significantly changed the terms of the offer, email messages sent to the seller are returned as undeliverable, or the

4: See Fields, supra note 36; see also Deborah Kong, Internet Auction Fraud Increases; Buyers Leam the Hard Way To Be Careful Who They Send Money To-But Sometimes There's A Happy Ending Anyway, U.S.A. TOI)AY, June 23, 2000, at 3B (quoting Holly Anderson, a spokeswoman for the National Consumer League).

${ }^{51)}$ See 2001 Internet Fraud Statistics, at http://www.fraud.org/internet/2001 stats $10 \mathrm{mnt}$.htm (last visited Mar. 9, 2002). This number is an increase from the $\$ 326$ average for 2000 . See Fields, supra note 36; Sheryl Harris, Intemet Fraud: Let the Bidder Beware, PI.AIN DE.Al.1.R, Aug. 17, 2000, at 1B; NCL Wams Consumers, supra note 41.

51 See John J. Kroll, So Far Cyberspace is Reasonably Safe, PI AIN DEALLR, July 19, 1999, at 1 C. ${ }^{52} I d$.

53 See Dennis Prince, Dirty Tricks: Online Auction Scams, at http://www.auctionwatch.com/ email/print.html?ret=awdaily/features/dirtytricks/index.html (Aug. 16, 1999).

See Faerber, supra note 32. 
feedback rating of the seller deteriorates after the bidder's initial bid. ${ }^{55}$

A second form of fraud arising during the bidding process is shill bidding, whereby a party puts in one or more false bids, with no intention of actually purchasing the item. ${ }^{56}$ Typically, parties employ different user names to make these fraudulent bids, bidding on either their own or their co-conspirators' offered items. ${ }^{57}$ Shill bids are made to drive up the price of the auctioned item or to generate some other benefit to the seller. ${ }^{58}$ For example, on some online auction sites, if a particular auction reaches a certain number of bids, the auction will be specially promoted on the site..$^{.9}$

In fairness to the online auction sites, shill bidding can be difficult to detect. Any individual can use multiple user names to participate in online auctions, alone or in concert with other shill bidders. ${ }^{60}$ Thus, a cursory examination of the list of bidders may not reveal collusion. Tracing collusive bidding is time-consuming, involving hours of sifting through and matching up myriad bidding histories

${ }^{5}$ Id. (quoting Kevin Pursglove of eBay). To further discourage bid shielding, as of August 1, 2001, eBay began prohibiting bid retractions within the last twelve hours of an auction. See Michelle Dennehy, eBay Updates Bid Retraction Rules, at http://www.auctionwatch.com/ email/print.html?ret=/awdaily/daily news/aug01/1-080101.html (Aug. 1, 2001); see also eBay Help: Buyer Guide: Bid: Retracting a Bid, at http://www.pages.ebay.com/help/ buyerguide/bidding-retract.html (last visited Mar. 9, 2002); Amazon.com: Help/Ordering from a Third Party/Auctions \& zShop.../Changing Your Bid, at http://www.amazon.com/exec/ obidos/tg/browse/-/537826/qid=997805.../103-3615039-942141 (last visited Mar. 9, 2002).

56 See Intemet Auction Fraud Report, supra note 11, at 4; see also Snyder, supra note 6, at 457; Jonathan Rusch, The Rising Tide of Intemet Fraud 2-3, at http://www.usdoj.gov/criminal/ cybercrime/usamay2001_1.htm (last visited Mar. 9, 2002).

According to Louis Richman, the financial editor of Consumer Reports, shill bidding and misrepresentation occur frequently online; although Consumer Reports has no statistics as of yet regarding incidents of shill bidding and misrepresentation, the magazine is designing a research project to study online auctions systematically. See The Bidding Game, supra note 12; see also Kong, supra note 49.

${ }^{57}$ See Maria O’Daniel, Recognising Common Net Scams, New Straits TimLs (MALAYSIA), Oct. 2, 2000, at 39.

${ }^{53}$ See Jamie Beckett \& Jon Swartz, Budder Beware, Say eBay Critics, S.F. Chron., Dec. 22, 1998, at B1.

59 Auctions on eBay that reach the thirty-bid level fall within eBay's "hot" category and earn a special promotion on the site. Id.

in) See The Bidding Game, supra note 12. 
and user feedback. ${ }^{61}$ Because of cost considerations and storage capacity issues, auction records may be expunged from an online auction site after a set number of days. This may affect the viability of any investigation into shill bidding or other forms of collusion, as the bidding record retention period may not be long enough to allow investigators to uncover shill bidders who spread out their fraudulent bids. $^{62}$

Even when a particular bidding history is still available, it typically reveals only the highest offer entered by each user name, which may mask the progress of bids. ${ }^{63}$ In addition, overlapping bids may not necessarily signal collusion, as some overlap may be coincidental, if not inevitable. Sometimes innocent bidding appears suspicious, especially in narrow areas of collecting where it stands to reason that there might be innocent overlap. ${ }^{64}$ Buyers and sellers interested in one sort of item, such as abstract art, will gravitate to those offerings, and sellers of those kinds of items may make multiple offerings in that area. Also, some buyers simply may prefer to buy from a seller with whom they have had a positive experience. ${ }^{65}$

Nonetheless, experts say that online auction sites can and should do more to prevent shill bidding. ${ }^{66}$ Critics claim that online auction sites are slow to take action on complaints about shill bidding. ${ }^{67}$ Arguably, online auction sites have a disincentive to eradicate shill

"il eBay uses proprietary software called "shill hunter" to check bidding histories for collusion. See infra note 114.

tiz eBay purges its records every thirty days. See The Bidding Game, supra note 12.

${ }^{13}$ Id.

it Id.

tis Id.

(i) According to Professor Eric Greenleaf of the Stem School of Business at New York University, "[t]here should be patterns that would be very suspicious. These companies have powerful computing ability, and it would be easy to search for coincidences. But it's timeconsuming, and eBay is very laissez-faire." Id.

177 See Beckett \& Swartz, supra note 58. According to eBay:

The Investigations Team attempts to resolve reported cases of inappropriate trading behavior. eBay will consider the circumstances of an alleged offense and the user's trading records before taking action.

Disciplinary action may range from a formal warning, up to indefinite suspension of a user's account. However, if we cannot prove your complaint with certainty, we make take no action.

eBay Help: Community Standards: Investigates, at http://pages.ebay.com/help/comments/ investigates.html (last visited Mar. 9, 2002). 
bidding, since tolerating shill bidding on their sites will drive up the selling prices, and thus ultimately result in greater commissions for the online auction sites because they receive some stated percentage of each online auction transaction. ${ }^{68}$

After the bidding has closed, additional opportunities for fraud emerge. ${ }^{69}$ The first and most common scenario is simply a failure by one party to perform. This typically occurs when a seller fails to deliver the promised goods after the buyer has paid in full, constituting fraud in the factum. ${ }^{70}$ A less common form of this scenario involves a successful bidder failing to complete the transaction by failing to pay for an item the seller has delivered. The cost of this form of fraud is evidenced by the seller having to undertake an entirely new auction, with the potential, despite the lack of culpability on the part of the seller, for a cloud on the transaction as a result of the existence of a second auction. ${ }^{71}$

A second form of online auction fraud that surfaces after the bidding has closed involves material misrepresentations of the items auctioned. The fraud occurs when a party is induced into a contract by a material misrepresentation, constituting fraudulent inducement. ${ }^{72}$ In this scenario, a buyer receives the item, but the item is not as it had been described. ${ }^{73}$

${ }^{68}$ eBay Help: Community Standards: Investigates, supra note 67.

69 See Kong, supra note 49.

${ }^{70}$ See supra notes 23-26 and accompanying text. More than eighty percent of the complaints the Federal Trade Commission receives stem from sellers' failure to deliver purchased and paid-for items to buyers. See Kong, supra note 49; see also Snyder, supra note 6, at 458; Rusch, supra note 56, at 2; Saul Hansell \& Judith H. Dobrzynski, eBay Cancels Ant Sale and Suspends Seller, N.Y. TIMEs, May 11, 2000, at A1; Internet Auction Fraud Report, supra note 11, at 7; Internet Fraud Watch Online Auction Tips, at http://www.fraud.org/news/ 1998/nov98/11 1698.htm (Nov. 16, 1998).

${ }^{71}$ See Snyder, supra note 6, at 458-59.

72 See supra notes 23-26 and accompanying text.

${ }^{73}$ Such activity can violate federal statutes prohibiting mail fraud, wire fraud and, if the auctioned item was stolen, may constitute transportation of stolen property across state lines. Fraud in online auctions is investigated as mail fraud, because the bidders send their money through the U.S. mail. See Beckett \& Swartz, supra note 58 (quoting postal worker Linda Kirksey of Fort Worth, Texas). The violation of statutes prohibiting transportation across state lines is relevant in the context of fraud only in the event that the seller's misrepresentation was as to seller's title to the goods in question. See Steven A. Hetcher, We Need To Avoid Tendency To Overregulate Online Auctions, MilwaukeEJ. SEnTINel, Dec. 5, 2000, at 17A; see also Snyder, supra note 6, at 458; Hansell \& Dobrzynski, supra note 70. 
Online auction fraud in its various forms is becoming an increasingly pervasive problem due to the lack of meaningful consumer protection in the form of appropriate regulation and enforcement thereof, as well as the dearth of consumer education efforts. The high number of complaints about online auction fraud illustrates the need for steps to be taken to protect consumers from being victimized by online auction fraud, and to provide meaningful relief in the event that consumers are so victimized.

\section{ONLINE AUCTION FRAUD LAWSUITS}

The increasing problem of online auction fraud is also evident in the nation's judicial dockets. A major component of the current governmental effort to curb online auction fraud is the prosecution of the perpetrators. Because of the ephemeral nature of information on the Internet, online fraud cases differ from traditional fraud cases, as data can be purged or reworked in such a way as to hinder investigation into suspected Internet fraud. ${ }^{74}$ Thus, these cases must be prosecuted differently. ${ }^{75}$ Since 1994, the FTC has brought 200 such actions against over 653 respondents or defendants, obtaining injunctions and ordering over $\$ 180$ million in redress or disgorgement. ${ }^{76} \mathrm{Of}$ the 200 cases, only five involved online auction fraud. ${ }^{77}$ Other law

" One hallmark of Internet fraud is the ability of perpetrators to cover their tracks and mask their location and identities. Lising anonymous emails, short-lived Web-sites, and falsified domain name registrations, many fraud operators are able to strike quickly, victimize thousands of consumers in a short period of time, and disappear without a trace.

FTC Statement on Internet Fraud, supra note 4, at 9; see also Tom Wolverton \& Greg Sandoval, Net Crime Poses Challenge to Authonties, CNET Niws.COM (Oct. 12, 1999), at http://news.cnet.com/news/0-1007-200-850601.html.

75. See Tracing in Intemet Fraud Cases: PairGain and NEI Webworld, at http:/ /www.usdoj.gov/criminal/cybercrine/usannay2001_3.htm last visited Mar. 9, 2002); see also Rovella, supra note 36 iquoting Christopher Painter, deputy chief of the Criminal Division's Computer Crimes and Intellectual Property section).

"The FTC has collected over $\$ 55$ million in redress for online fraud victims. See FTC Statement on Intemet Fraud, supra note 4, at 2-3, n.9; see also Commission Enforcement Actions Involving the Intemet and Online Senves), at http://www.ftc.gov/bcp/internet/cases-internet.pdf(Oct. 1, 2001: [hereinafter Commission Enforcement Actions].

i7 The remaining cases involved other forms of Internet fraud, including Internet service provider scams, pyramid schemes, and health care fraud. See Law Enforcers Target "Top 10" Online Scams; Consumer Protection Cops From 9 Countries, 5 U.S. Agencies, And 23 States Tackle Intemet Fraud, at http://ww.ftc.gov/opa/2000/10/topten.htm (Oct. 31, 2000) [hereinafter Law 
enforcement agencies are prosecuting online auction fraud as well. In late 1999, Robert Guest had the distinction of receiving the first federal prison sentence resulting from online auction fraud. ${ }^{78}$

Two online auction fraud cases have garnered the lion's share of press. The first case is notable both for its timing and its impact on how the FTG approaches online auction fraud, and the second case is notable for its scope. Although the government was successful in both cases, judicial action is not the most cost-effective approach to dealing with online auction fraud. However, the facts of these two cases illustrate the critical need for additional efforts to protect consumers from being victimized by online auction fraud, and to provide avenues for meaningful relief in the event that they are so victimized.

\section{A. The Hare Case}

In its first action against an online auction seller, the FTC alleged that Mr. Hare of Lake Worth, Florida, violated the Federal Trade Commission Act and the Mail or Telephone Order Merchandise Rule by offering computers and related equipment for sale via online

Enforcers Target Top 10]. Four of the five FTC-prosecuted online auction fraud cases to date involve failure to deliver computers to the successful bidder. See Federal Trade Commission $v$. Auction Saver, LLC, Complaint for Injunctive and Other Equitable Relief, at http://www.ftc.gov/os/ 2000/10/auctionsavercomplaint.pdf (last visited Mar. 9, 2002); Intemet Auctioneer Settles FTC Charges, at http://www.ftc.gov/opa/2001/08/computerbyus.htm (Aug. 30, 2001); Federal Trade Commission v. Michael Dewhurst, Complaint for Permanent Injunction and Other Equitable Relief, at http://www.ftc.gov/os/2000/10/empireauctioncomplaint.htm (last visited Mar. 9, 2002); Complaint for Injunction and Other Equitable Relief, at http://ftc.gov.os/1998/9804/compl3.htm (last visited Mar. 9, 2002) [hereinafter Hare Complaint]; see also infra notes 78-82 and accompanying text (discussing the Hare case). The fifth online auction case is currently under seal and thus no information is publicly available at this time. See Commission Enforcement Actions, supra note 76, case number 165, at 66.

${ }^{78}$ See Krebs, supra note 30. In late 1999, Robert Guest plead guilty to mail fraud and was sentenced to fourteen months in prison and ordered to pay over $\$ 101,000$ to his victims. Mr. Guest netted $\$ 37,000$ by auctioning non-existent goods, using the alias "Darren Jay Farmer." He created a reputable "seller's history" for himself on eBay before he accepted bids and payments for merchandise he never delivered. See Kristina Stefanova, Cyber Con Men Beware, Insight ON THE News, Apr. 17, 2000, at 27; see also Dennis Prince, Fraud's Silver Lining, at http://www.auctionwatch,com/awdaily/viewpoint/speakout/silverlining.html (Aug. 16, 1999); Michelle Dennehy, eBay User in Fed Slammer, at http://www.auctionwatch. com/email/print.html?ret=/awdaily/dailynews/novem.../2-1 10399.htm (Nov. 3, 1999); Man Sentenced for eBay Fraud, CNET.COM NEwS (Nov. 2, 1999), at http://news.cnet.com/ news-1007-200-1427746.html. 
auction sites, accepting payment and failing to deliver the goods. ${ }^{79}$ He took as much as $\$ 1,450$ from each successful bidder but never sent the computers or refunded the money. ${ }^{80}$

Ultimately, Mr. Hare pled guilty to wire fraud. ${ }^{81}$ He was sentenced to six months home detention, three years probation and was ordered to pay restitution of over $\$ 22,000{ }^{82}$ Furthermore, pursuant to a request by the FTC, Mr. Hare was banned from doing business on the Internet. ${ }^{83}$

The Hare case is notable for more than its distinction as the first online auction fraud prosecution by the FTC. Although the FTC was successful in Hare, the litigation prompted the FTC to develop a comprehensive, three-pronged approach to fighting online auction fraud in an effort to prevent online auction fraud before it occurs, thus obviating the need to expend the financial and other resources necessary for a successful prosecution. ${ }^{8+}$ The approach consisted of

7: See Hare Complaint, supra note 77; see also Intemet 'Entrepreneur' Sentenced for Wire Fraud, at http://www.ftc.gov/opa/1999/9902/hare3.htm (Feb. 17, 1999) [hereinafter Entrepreneur Sentenced]. Mr. Harc stated in advertisements that he was marketing "Micron 266, MHZ Pentium II computers with monitors," "Toshiba Satellite Pro 410 DCT" computers, and hard drives. See FTC Halts Internet Auction House Scam, at http://www.ftc.gov/opa/ 1998/9804/hare.htm Apr. 13, 1998 [hereinafter FTC Halts Scam]; see also Internet Merchant Barred for Lifefrom "Net based" Commerce, at $\mathrm{http}$ // /www.ftc.gov/opa/1998/9809/auction.htm (Sept. 8, 1998).

3*) See FTC Halts Scam, supra note 79.

81 The FTC requested and was granted a temporary restraining order and a freeze on $\mathrm{Mr}$. Hare's assets, pending trial. The FTC further referred the case to the FBI in West Palm Beach, Florida, and the U.S. Attorney for the Southern District of Florida. See Entrepreneur Sentenced, sufra note 79.

${ }^{82}$ Id: see also Online Auction Fraud Cases, supra note 33; Entrepreneur Sentenced, supra note 79.

03. The Court issued a stipulated permanent injunction banning Mr. Hare from using the Interncl to "advertise, market or otherwise offer for sale any goods or services." See Tom Lowry, On-line Auttioneer eBay Raises Web Site Security, U.S.A. ToDAY, Feb. 15, 1999, at 6B; see also Going, Going, Gone, supra note 42, at 7 . Before the stipulated final order, the Court issued a temporary restraining order with the asset freeze. The Court then approved the parties' stipulation to an extended, modified temporary restraining order. See FTC Halts Scam, supra note 79; see also Entrepreneur Sentenced, supra note 79.

4 Notwithstanding our important law enforcement activities, the Commission recognizes that lawsuits alone cannot adequately protect consumers. Consumers must be empowered to protect themselves in the new interactive world. As such, the Commission develops and encourages consumer education efforts and has prompted industry to develop new technologics that afford consumers more control over their transactions. 
training law enforcement personnel, tracking online auction fraud, and educating consumers. First, with respect to training, investigators would be taught to uncover and prosecute online fraud and would be instructed on how to educate consumers about online fraud..$^{85} \mathrm{Next}$, with respect to tracking online auction fraud, the FTC would use its "Consumer Sentinel" program to identify perpetrators and to refer potential Internet fraud cases to the appropriate law enforcement agencies, while undertaking certain prosecutions itself. ${ }^{86}$ Consumer Sentinel is a web-based, binational, multi-state computerized consumer fraud database that uses the Internet to provide secure access to over 300,000 consumer complaints from over 300 law enforcement organizations across the United States and Canada. ${ }^{87}$ Finally, with respect to consumer education, the FTC would work with the online auction sites to encourage the sites' adoption of additional consumer protection measures, while the FTC continued its own consumer education efforts. ${ }^{88}$

The FTC's efforts to date are steps in the right direction, but training, tracking, and consumer education are insufficient to control the escalating problem of online auction fraud. ${ }^{89}$ The FTC, as the

Mozelie W. Thompson, Presentation: The Challenges of Law in Cyberspace-Fostering the Growth and Safety of E-Commerce, 6 B.U. J. SCI. \& TECH. L. 1, 3 (2000).

${ }^{85}$ See Going, Going, Gone, supra note 42; see also Fields, supra note 36.

${ }^{86}$ See Going, Going, Gone, supra note 42, at 2. Complaints and inquiries come to Consumer Sentinel through the FTC's Consumer Response Center at the rate of 12,000 per week. See FTC Statement on Internet Fraud, supra note 4, at 14.

${ }^{87}$ See Consumer Sentinel, at http://www.consumer.gov/sentinel/index.html (last visited Mar. 9, 2002). In 1998, 8,000 Internet-related complaints were registered with Consumer Sentinel. In 1999, the number of complaints rose to 18,600. See Internet Fraud-Working Group On Unlawful Conduct on the Internet B-l app., at http://www.usdoj.gov/ criminal/cybercrime/append.htm\#B (last visited Mar. 9, 2002). In 2000, over 100,000 complaints were entered into Consumer Sentinel. See Consumer Sentinel: Fraud Trends, at http://www.consumer.gov/sentinel/trends.htm (last visited Mar. 9, 2002); see also Boom in E-Commerce Has Created Fertile Ground for Fraud: FTC, at http://www.ftc.gov/opa/ 2001/05/iftestimony.htm (May 23, 2001).

${ }^{88}$ According to the FTC, meaningful consumer protection requires: "(1) coordinated law enforcement against fraud and deception; (2) private initiatives and public/private partnerships and (3) consumer education through the combined efforts of government, business, and consumer groups." FTC Statement on Consumer Protection, supra note 5, at 3; see also Snyder, supra note 6, at 463.

${ }^{89}$ FTC-initiated prosecutions are becoming increasingly common. With the favorable results in Hare, it is clear that the FTC is capable of protecting consumers in some sense. However, civil actions brought against individuals can only be so effective. 
federal government's primary consumer protection agency, must use its substantial regulatory authority to force the online auction sites to take responsibility for fraud prevention in the only way the sites will understand--by subjecting them to financial liability for fraud on their sites. ${ }^{90}$

\section{B. The Walton Case}

The other online auction fraud case to gain widespread attention was the federal government's prosecution of Mr. Kenneth Walton of Sacramento, California. In what is believed to be the first criminal case resulting from shill bidding online, and certainly one of the most notorious of such cases, ${ }^{91}$ the federal government charged Mr. Walton with wire fraud and mail fraud in connection with online auction fraud. ${ }^{92}$ Mr. Walton, with help from two co-defendants, put an abstract painting up for auction on eBay, trying to create the impression that the work was painted by American modernist Richard

Rather than investigating every individual case of fraud, it would be much more efficient and ultimately beneficial to the consumer if the FTC turned the focus of its attention on the auction houses themselves. Making the auction houses responsible for the fraudulent conduct would implore them to take all steps necessary to protect the consumer.

Snyder, supra note 6, at 464-65; see also Statement of Jodie Bemstein on Intemet Auction Fraud, at http://www.ftc.gov/opa/2000/02/jodiestatement.htm (Feb. 14, 2000); Online Auction Fraud Cases, supra note 33.

:*i See FTC Staternenl on Intemet Fraud, supra note 4, at 1-2; see also Snyder, supra note 6, at 464. The FTC has as its primary legislative mandate the enforcement of the Federal Trade Commission Act, which prohibits "unfair or deceptive practices in or affecting commerce." See Federal Trade Commission Act, 15 U.S.C. $\$ 45(a)$ (1994).

"The Federal Trade Commission has interpreted its enabling legislation as allowing it to regulate E-commerce and it has interpreted its rules conceming things such as fair marketing practices and mandatory disclosures as applying to the Internet." 1998 Intemet Fraud Statistics, at http://www.fraud-org/internet/9810stat.htm (last visited Mar. 9, 2002) [hereinafter 1998 Fraud Statistics]; see also infra notes 132-45 and accompanying text (discussing suggested areas for regulation).

"1. See Eric Young, Two Men Plead Guily in eBay Sam, IvDUSTRY STANDARD, at http://www.thestandard.com/au/articles/artidcle_print/0,1454,13810,00.html (Apr. 18, 2000) (on file with the author).

See Indictment at 1, United States v. Fetterman, Walton \& Beach [hereinafter Walton Indictment] (on file with the author). 
Diebenkorn. ${ }^{93}$ The Walton case demonstrates the need for safeguards in the online auction process - safeguards that can most easily be instituted and financed by the online auction sites themselves. These safeguards include mandatory consumer education efforts, identity and credit-worthiness verification for all online auction participants, low-cost or free escrow services, insurance for the full value of transactions, and authentication of offered items. ${ }^{94}$

From October 1998 through May 2000, the defendants devised and participated in a scheme to defraud eBay users by engaging in a bidding ring. ${ }^{95}$ They created false aliases not traceable to their real identities, provided fraudulent feedback on each other's user names, and placed fraudulent bids. ${ }^{96}$ For some of their multiple user names, they appropriated the last names of famous artists, to give the impression that some family member of the famous artist was the bidder. The total value of the winning bids in the auctions hosted by the defendants, using shill bidding, exceeded $\$ 450,000 .^{97}$

Mr. Walton forged the initials "RD 52" on the bottom right corner of the fraudulent Diebenkorn, adjacent to a hole in the painting, in an

${ }^{93}$ Kenneth Fetterman and Scott Beach were charged along with Mr. Walton. Id. at 1,10; see also Mark E. Wojcik, Lawyers Who Lie On-Line: How Should the Legal Profession Respond to eBay Ethics?, 18 J. MARSHALLJ. COMPUTER \& INFO. L. 875, 876 (2000).

${ }^{94}$ See infra notes $132-45$ and accompanying text.

${ }^{95}$ See Walton Indictment, supra note 92, at 5.

Records from eBay and from e-mail service providers confirm that Fetterman and his co-schemers shielded their true identities from $\mathrm{eBay}$ and its users by providing bogus names, and postal addresses obtained from free email providers known to collect little or no verifiable information on their account holders. By creating multiple User Ids, Fetterman and his co-schemers intended to deceive other eBay users into believing that the fraudulent or "shill" bids they placed on each other's items were, in fact, legitimate.

Compl. at 6, United States v. Fetterman, (Feb. 2, 2001) Ida Aff., (Special Agent, Internal Revenue Service, Criminal Investigations) (on file with author).

96 These fraudulent bids

constituted misrepresentations that [the defendants] were legitimate and independent eBay users who intended, and were willing, to pay the amounts they bid on those items. By making these misrepresentations, [the defendants] intended to defraud other eBay users by causing them to place significantly higher bids for the items than they would have absent the fraudulent bids.

Walton Indictment, supra note 92, at 4; see also John Schwartz \& Judith H. Dobrzynski, $3 \mathrm{Men}$ are Charged with Fraud in 1,100 Ant Auctions on eBay, N.Y. TIMES, Mar. 9, 2001, at A1; Young, supra note 91 .

${ }^{97}$ See Walton Indictment, supra note 92, at 8. 
effort to defraud bidders into thinking the work was painted by the renowned California artist. ${ }^{98} \mathrm{Mr}$. Walton included three digital pictures of the painting, including a close up shot of a hole in the bottom right corner near the forged initials. ${ }^{99}$ To foster the image that he was unsophisticated in matters of art, Mr. Walton listed the painting under his eBay user name "golfpoorly," which had little history of trading in art. ${ }^{100}$ His fellow defendants, under a variety of user names, provided positive feedback for "golfpoorly." 101 To further the impression of his lack of sophistication, he included the painting along with a deflated basketball, a Mexican voodoo mask, and an unopened roll of twine. ${ }^{102}$ He set the minimum bid on the piece at 25 cents. In his written description of the painting, Mr. Walton claimed that he bought the painting at a garage sale in Berkeley, California, before he was married, ${ }^{103}$ and that his child had punctured a hole in it with his Big Wheel tricycle. ${ }^{104}$

In reality, Mr. Walton had no wife, no child and thus (one assumes) no Big Wheel. He purchased the unsigned abstract painting from a secondhand store in Little Rock, California, not in Berkeley. ${ }^{105} \mathrm{Mr}$. Walton chose Berkeley as the alleged location of the painting to promote the false impression that the painting came from the area where Mr. Diebenkorn painted in the early 1950s. ${ }^{106}$ The tale of his mythical child's tricycle accident was designed to draw the bidders' eyes to the hole, adjacent to the forged initials. ${ }^{107}$ According to the government, these statements were "misrepresentations designed to

Id. at 9 .

See Walton Complaint, supra note 95, at 10.

114i See Kerneth Walton Plea Agreement at 16 (Apr. 17, 2001) Thereinafter Walton Plea Agreement] (on file with the author).

${ }_{1 ! n}$ See Walton Indictment, supra note 92, at 9-10.

${ }^{112}$ See Walton Indictment, supra note 92, at 9; see also Walton Plea $\Lambda$ greement, supra note 100 , at 17.

${ }^{1113}$ See Judith H. Dobrzynski, Online Seller of Abstract Work Adds a Money-Back Guarantee, N.Y. Timis, May 10, 2000, at Al; see also Jonathan Curiel et al, eBay Bids Probed By FBI, S.F. ChroN., June 7, 2000, at A3.

1hit See Walton Indictment, supra note 92, at 10; see also Hansell \& Dobrzynski, supra note 70.

115: See Walton Indictment, supra note 92, at 8-9.

I!nj See Walton Complaint, supra note 95, at 11; see also Walton Indictment, supra note 92, at 10 .

${ }^{111}$ See Walton Complaint, supra note 95, at 11; see also Walton Indictment, supra note 92 , at 10 . 
deceive potential bidders into increasing their bids on Walton's painting." 108

Although Mr. Walton made no affirmative claims about the identity of the artist, there was rampant speculation fueled by $\mathrm{Mr}$. Walton's story that the work was in fact by Diebenkorn. ${ }^{109}$ The three defendants' fraudulent bids on the painting drove the price up to $\$ 135,805 .{ }^{110}$ When the press picked up the story, Mr. Walton said that he would cancel the legally binding sale if experts determined that the painting was not in fact painted by Diebenkorn, and if the buyer, Rob Keereweer of the Netherlands, wanted to rescind the sale. ${ }^{111}$ Mr. Walton denied faking the painting or adding the initials. He acknowledged to Mr. Keereweer that he had "made up a little story to go with the painting." The parties then decided to put off the transaction temporarily. ${ }^{12}$

After significant attention by the press, eBay cancelled the sale, contending that Mr. Walton had engaged in shill bidding, and suspended Mr. Walton's trading privileges, first for thirty days, and then permanently. ${ }^{113} \mathrm{Mr}$. Walton's painting drew ninety-five bids, but according to the bid history compiled by eBay, ${ }^{114}$ these bids were

\footnotetext{
${ }^{1018}$ See Walton Complaint, supra note 95, at 10.

109 See Dobrzynski, supra note 103; see also The Bidding Game, supra note 12; Wojcik, supra note 93, at 876-89.

${ }^{110}$ One bidder withdrew his bid after Walton would not let him inspect the painting in person. See Dobrzynski, supra note 102; see also Walton Indictment, supra note 92, at 12; Schwartz \& Dobrzynski, supra note 96; The Bidding Game, supra note 12.

${ }^{111}$ See Dobrzynski, supra note 103. However, just before the auction closed, Mr. Walton added the following description of the painting:

This painting is sold in the same manner as the other items I am selling on eBay and requires full payment within 7 days of the auction, in advance of delivery to the buyer, and is sold as described in the auction description, without representation as to authorship or authenticity.

Wojcik, supra note 93, at 886.

112 See Dobrzynski, supra note 103.

${ }^{113}$ Mr. Walton's suspension from eBay "had nothing to do with the authenticity of the painting or the story he invented to go with the work." He was suspended for shill bidding. See The Bidding Game, supra note 12.

${ }^{114}$ According to Kevin Pursglove of eBay:
}

[B]ecause approximately 6 million items are listed on eBay each day, it would be impossible to catch each and every fraudulent action as it occurs. However, eBay's new proprietary software tools gives the online auction leader the best possible chance to do so, Pursglove said. The software searches the bidding history of individual bidders to look for historical shill patterns, and identifies shill patterns as they are 
made by just seventeen user names, ${ }^{115}$ who turned out to be a total of five individuals, including Mr. Walton and his two co-defendants, using multiple user names."

The very attention that $\mathrm{Mr}$. Walton cultivated to drive up the price of the painting ultimately brought him to the attention of law enforcement. The FBI opened its investigation after reading a newspaper article detailing Mr. Walton's claims about how he gained possession of the painting. ${ }^{17}$ In March 2001, Mr. Walton, along with Scott Beach and Kenneth Fetterman, was indicted on charges of participating in a bidding ring that cost art buyers a total of $\$ 450,000 .^{18}$ The thirty-five-page indictment charges the three with sixteen separate counts of wire and mail fraud in connection with 1,100 auctions between October 1998 and May 2000, including the auction of the purported Diebenkorn. ${ }^{19}$ Each count carries a maximum penalty of up to five years in prison and $\$ 1$ million in fines. ${ }^{120}$

Mr. Walton and Mr. Beach pled guilty on April 17, 2001, pursuant to plea agreements with the federal government. ${ }^{121} \mathrm{Mr}$. Fetterman remains at large, and his girlfriend has been charged with harboring or concealing him. ${ }^{122}$ Under the terms of the plea agreements, both

occurring.

Michael Mahoney, eBay Scam Artists Face Criminal Charges, E-COMMERce TIMES (Mar. 9, 2001), at http://www.newsfactor.com/perl/printer/8086 (on file with the author).

11.) See The Bidding Game, supra note 12.

"lli Id.

"Id. Isee also Wojcik, supra note 93, at 889-90.

$11: 3$ See Schwartz \& Dobrzynski, supra note 96.

11: The three men used over forty user names and "buoyed prices and intended to trick other bidders into believing that the sellers were respected users of eBay." Id.

$1: I d$.

${ }^{121} \mathrm{Mr}$. Walton had to turn over the fake Diebenkorn to the government, agree to a summary disbarment from the California State Bar and agree to cooperate fully with the government, in exchange for a recommendation of leniency. See Walton Plea Agreement, supra note 100 , at $2-4$.

1:2 If convicted, Ms. Galipeaux faces up to five years imprisonment and a $\$ 250,000$ fine. See Warrant for Arrest of Terri Ann Galipeaux (on file with the author); see also Woman Indicted For Harboring Fugitive in eBay Shill Bidding Case Involuing Sale of Fake Diebenkorn Painting for $\$ 135,805$, at 1 , at http://www.usdoj,gov/criminal/cybercrime/galipeaux_indict.htm/June $20,2001 \%$. 
Mr. Walton and Mr. Beach agreed not to participate, directly or indirectly, in online auctions for a specified period. ${ }^{123}$

The significant attention paid to the Walton case by the media illustrates how easy it is to commit fraud in an online auction, and demonstrates the lack of consumer protection available for online auction participants unless and until the government steps in to prosecute the perpetrator. The government ultimately stopped Mr. Walton and his co-defendants, but that same press attention may have inspired other would-be Waltons to try their hand at online auction fraud. In the absence of effective regulation of online auctions and vigilant enforcement thereof, innocent victims have no protection from online auction fraud and no avenue for relief in the event they are so victimized.

Successful prosecution of any fraud case, including online auction fraud cases, is useful in that it stops a particular defendant from perpetrating a particular fraud for some particular period of time. But an ex post facto approach, focusing on prosecution instead of prevention, misses the opportunity to halt fraud before it occurs. The increasing numbers of online auction participants and online auction fraud complaints make this missed opportunity even more troublesome than in the context of traditional or offline auctions. The primary problem with the existing approaches to fighting online auction fraud is that almost all of the prohibitions and consequences focus on fraud that has already occurred. Efforts should be expended in proactive prevention through consumer education, and through the imposition of mandatory fraud prevention efforts on the online auction sites, with financial liability for any failure to comply with the requirements. These efforts would go a long way toward reducing online auction fraud, with the costs borne by the parties who directly benefit from the transactions: the online auction sites.

\section{Gurbing OnLINe Auction Fraud Through REGULATION, ENFORCEMENT, AND CONSUMER EDUCATION}

The high numbers of complaints about online auction fraud highlight the absence of any meaningful consumer protection for online auction participants. This dearth of consumer protection stems from the lack of sufficient regulation of online auctions, the lack

${ }^{123}$ Walton Plea Agreement, supra note 100, at 6. 
of any meaningful enforcement of existing regulation, and the lack of sufficient consumer education efforts with respect to online auction fraud.

It is unrealistic, of course, to aim to wipe out online auction fraud through the enactment of regulation alone. ${ }^{124}$ Vigilant governmental enforcement of such regulations and consumer education efforts are necessary components of any successful effort to curb online auction fraud. Thus, a better approach would be a comprehensive governmental effort involving regulation of online auction sites, enforcement efforts, and consumer education about the dangers of online auctions. ${ }^{125}$ The online auction sites must be legally required to take delineated steps to reduce online auction fraud, with the threat of financial liability for any failure to do so. ${ }^{126}$ Unless and until the online auction sites are held financially responsible for fraud on their sites, they have no real incentive to clean up fraud beyond the minimum necessary to ensure a customer base using (and thus paying for) their sites' services. Additionally, because of the low dollar amount in the average online auction transaction, and the enforcement costs associated with pursuing a fraud claim, defrauded consumers and fraud investigators have a financial incentive not to force the issue. Since the online auction sites are paid with a percentage of each transaction and control the procedures in place on their sites, they are in the best position to take steps to curb fraud and to make defrauded consumers whole.

\section{A. Regulating Online Auction Sites}

The absence of regulation of online auction sites can be attributed to several factors. Lawmakers may have been slow to react to the rise in online auction fraud because of the rapid pace of technological development and the scarcity of resources initially devoted to the problem. ${ }^{127}$ The paucity of meaningful regulation of online auctions may also be a function of the relative newness of the Internet as a

\footnotetext{
121 See Hetcher, supra note 73.

125 Id.

12: "Penalties must be strong enough to act as real deterrents to fraud. Monetary penalties should be substantial, and egregious or repcat oflenses should be treated as crimes." Id. at 5.

${ }^{127}$ See Trends Report, supra note 48, at 12; see also Snyder, supra note 6, at 456; Hetcher, supra note 73
} 
significant medium of retail commerce. Lawmakers may be hesitant to construct a regulatory scheme over a mode of commerce they do not yet fully understand. Faced with other pressing demands, lawmakers may take the position that the policy "caveat emptor"-let the buyer beware - has worked for years, so why not let that be the legislative solution with respect to online auction fraud? ${ }^{128}$ This position is evidenced by the application of existing laws designed for a different jurisprudential landscape to a wide variety of Internet crimes, albeit with varying degrees of success. ${ }^{129}$

To move beyond caveat emptor, lawmakers may feel they need to enact significant new legislation tailored exclusively for the online auction industry. Arguably, no significant new legislation is required, as the fraudulent activity taking place online is already illegal; a party making a material misrepresentation of a past or present material fact with scienter and the intent to induce reliance, who in fact does induce justifiable reliance, has committed fraud. ${ }^{130}$ Moving a fraud

\footnotetext{
128 See Finn et al., supra note 29 , at 350 .

129 Rather than amending every traditional criminal statute to deal with the rapidly growing industry of computer crimes, Congress, in 1984, enacted the Counterfeit Access Device and Computer Fraud and Abuse Law, 98 Stat. 1837, 2190 (codified at 18 U.S.C. $\S$ 1030). The law treated computer-related crimes as distinct federal offenses and was narrowly drawn to prohibit a limited range of offenses, such as those involving classified government information, and information of financial and consumer institutions. Subsequently, as computer-related crime grew and new issues emerged, the volume of federal and state legislation increased. In 1986, the Computer Fraud and Abuse Act was enacted. That law was amended numerous times, including in 1996, with the National Information Infrastructure Protection Act, 18 U.S.C. $\$ 1030$.
}

The federal mail and wire fraud statutes have also been used to protect against computer crime. 18 U.S.C. $\$ \S 1341,1343$. The statutes prohibit using interstate wire communications or the mails to further a fraudulent scheme to obtain money or property. Computer-aided theft involving the use of interstate wires or mails is prohibited by the laws.

Zegas, supra note 16 , at 24 .

${ }^{130}$ According to Commissioner Thompson of the FTC, "[w]e are not in completely uncharted territory, however. We already have in place a legal framework for consumer protection and for choice of law and jurisdiction. Applying those principles to e-commerce poses special challenges." See Thompson, supra note 84, at 6; see also Wojcik, supra note 93, at 894 .

More U.S. Attorneys" offices are pursuing significant Internet fraud cases. "The cases being prosecuted tend to show that the criminal statutes that apply to other types of white collar crime-conspiracy, mail and wire fraud, credit card fraud, securities fraud, money laundering, and identity theft- are equally applicable to various forms of Internet fraud." Rusch, supra note 56, at 7 . 
transaction to the online auction arena does not alter that result, but it does add to the transaction an additional party, the online auction site. The site controls the very introduction of the parties, and in fact, enables the parties to accomplish the transaction, making it appropriate to assign it some degree of responsibility for any fraud occurring on its site. Modifications to the existing legal structure through regulation can serve to bring the unique characteristics of online auctions within the letter of the law by requiring the online auction sites to take financial responsibility for any failure on their part to take steps to reduce fraud on their sites. ${ }^{131}$

Appropriate regulation of the online auction industry requires leveling the playing field. The most logical place to start is by holding online auction sites financially liable for fraud occurring on their sites. Because the online auction sites control the procedures in place on their sites and take some percentage of each transaction, the online auction sites are in a good position to prevent fraud and to indemnify defrauded participants for their failure to do so. The online auction sites should not be held to the status of absolute insurers for the validity of transactions. Instead, a comprehensive regulatory scheme superimposed on the online auction industry, setting out the specific steps the online auction sites must follow to prevent fraud, is needed. ${ }^{132}$ Failure to adequately comply with these regulations

1:31 Law enforcement agencies must have sufficient tools to protect consumers from harm and cnsure a fair and level playing field in the marketplace. Law and regulations that provide clear guidance for how legitimate marketing should be conducted, prohibit abusive practices, and enable agencies to prosecute violations swiftly and effectively, are important tools in the battle against fraud ... . While general statutes and regulations concerning unfair or deceptive acts or practices clearly apply to online marketing, legislative and regulatory bodies should consider whether specific requirements, prohibitions and penalties are needed in relation to electronic commerce.

NCI. Report, supra Iiote 17, at 5.

1:32 The dilemma between fostered market growth and governmenu montoring does not lesscon the strong public policy interests involved. Government has an interest in cnsuring the e-commerce confidence reinforces e-commerce as a viable commercial mcdium, benefiting both e-business and e-consumers. Without government action, e-consumers may adopt vigilantism to fight e-business abuses. Yel, government ecommerce action must be calculated and targeted, balance market and social policics in the process, take the intemet mechanisn into consideration and not eliminate ecommerce's attraction -fficiency, low cost, easily arcessible consumer base and the simultaneous nature of business transactions. 
should result in financial liability for the online auction sites. ${ }^{133}$

The regulations should attempt to shine a light on online auctions, removing the dark places where perpetrators of fraud lurk. First, online auction sites should be required to educate consumers about the potential for fraud in online auctions, including explanations of the various forms of online auction fraud and the ways consumers can protect themselves, or at least minimize their risks. These educational messages should be required to be affirmatively acknowledged by each user by clicking on a box prior to even viewing offered items on an online auction site. ${ }^{134}$ Furthermore, all online auction sites should be required to provide direct links to both sites that educate consumers about the possibility of online auction fraud and to sites that accept reports of online auction fraud. ${ }^{135}$

John R. Aguilar, Over the Rainbow European and American Consumer Protection Policy and Remedy Conflicts on the Intemet and a Possible Solution, 4 INI"1. J. COMM. L. \& POL'Y 1, 10-11 (1999/2000).

${ }^{133}$ In order to handle the growing problem of online auction fraud definitively, the FTC must come forth with a succinct legal framework to guide the industry in its pursuit of fraud free transactions. The FTC should mandate certain procedures that every online auction house must follow in order to escape the potential for being liable if a fraudulent transaction occurs.

Snyder, supra note 6 , at 471 .

No matter what the FTC ultimately decides to do, one thing is clear. The final guidelines must place liability upon the online auction house itself. The auction house is clearly in the best position to oversee and police the entire auction community to which it plays host. Rather than chasing the numerous fraudulant users and continuing to strain the already thin law enforcement agencies, the most efficient and effective method to end online auction fraud is to hold the hosts of the very place where fraud occurs liable for the actions of its users. Once liability has attached, the online auction houses will be quick to implement strict user policies in an effort to end the very harm its Web site fosters.

Id. at 472 .

${ }^{134}$ For example, the FTC offers tips on its website to help consumers when they "go global." See FTC Consumer Alent! Going Shopping? Go Global! A Guide for E-Consumers, at http://www.ftc.gov/bcp/conline/pubs/alerts/glblalrt.htm (last visited Mar. 9, 2002) [hereinafter FTC Consumer Alert]. The Internet Fraud Watch Website provides "Online Auction Tips" to help educate consumers. See Internet Fraud Watch, Online Auction Tips, at http://www.fraud.org/internet/inttip/aucttip.htm (last visited Mar. 9, 2002). The Department of Justice also has tips for consumers on its website. See Internet Fraud, supra note 16 , at 12 .

135 These sites include the NFIC, at http:/ /www.fraud.org/welmes.htm (last visited Mar. 9, 2002); the FTC, at http://www.ftc.gov (last visited Mar. 9, 2002); and the IFCC, at http://www.ifccfbi.gov/index.asp (last visited Mar. 9, 2002) [hereinafter IFCC]. 
The identities of all buyers and all sellers should be authenticated at no cost to the parties. This simply should be a cost of doing business for the online auction sites. Online auction sites reccive a percentage of the successful bid and should bear some responsibility for cutting off this avenue for fraud. This identity validation can be done through any reputable credit agency. ${ }^{136}$ Further, online auction sites should strictly limit the number of user names any one person can have. This may be an inconvenience to some innocent parties who have legitimate reasons for multiple user names, but it also decreases the potential for fraudulent participants to hide behind a cloak of anonymity, which decrease may, in and of itself, increase buyers' confidence in the online auction process. ${ }^{137}$

The creditworthiness of both parties should be authenticated. There are opportunities for fraud by both buyers who fail to pay and sellers who fail to deliver. Online auction sites should require a valid credit card with sufficient available credit to cover the value of the goods offered for sale before any participant is permitted to offer to sell or buy. ${ }^{1: 38}$ This adds a step to the auction transaction, but at essentially no real cost to the participants. If participants cannot provide this, arguably, their ability to honor their end of the transaction should be considered suspect.

All payments for auctions, in excess of some de minimis amount, should be processed through escrow agents, either independent or inhouse at the online auction site, but in any event, free to the partici-

\footnotetext{
13t) See infra notes 191-94 and accompanying text for a discussion of what online auction sites are doing in this area.

${ }^{137}$ Some of the suggested measures may ultimately prove cost prohibitive for the online auction commmity to implement. If this is so, the spirit of the suggested guidelines should prevail. Every participant should undertake all necessary procedures to ensurc the most complete information about every other participant. Cooperation and communication on every end will result in greater use of online auctions, an outcome sure to please the online auction houses as well as the individual. Cooperation begets currency.

Snyder, sugra note 6 , at 472.

${ }^{133}$ In late 1999, eBay began requiring its new sellers to provide a credit or debit card in order to list an item for the first time on the site. According to eBay, the increasing number of fraud cases brought to eBay's attention was one reason for the new requirement. See Andy Roe, eBay Adds Credit Card Requirement, at http://www,auctionwatch.com/email/print. html?ret $\Rightarrow /$ awdailynews/octob...4=102299.htm (Oct. 22, 1999) (on file with author).
} 
pants. The escrow agent will hold the buyer's funds until the purchased item arrives, in the promised condition. ${ }^{139}$

Online auction participants should be allowed to purchase insurance to cover the full amount of their transactions. The online auction sites can outsource this obligation or provide the insurance themselves, in any case for the full value of the transaction, at some reasonable price. ${ }^{140}$

The existence and quality of the merchandise offered for sale should be represented to, or evaluated by, the buyer as a condition of being offered for sale on the auction site. For items valued above some stated amount, an appraisal from a licensed expert should be provided to the buyer, who can ascertain the validity of the appraisal. In the alternative, sellers should be required to permit inspection of the goods by the buyer or buyer's representative prior to the start of any auction. ${ }^{141}$

The online auction sites should be required to maintain accurate records of the complete bidding histories of their transactions for some stated period of time sufficient to permit third-party inspection of suspected fraud. The online auction sites' cost and storage capacity issues should be subordinated to the best interests of their participants. ${ }^{142}$

Any failure to enforce these requirements should result in financial penalties to the online auction site involved, with assistance from all necessary law enforcement personnel. ${ }^{143}$ These penalties must be substantial enough to operate as an incentive for the online auction sites to deter fraud, and repeat offenses should be treated as crimes. ${ }^{144}$ Online auction sites can then use their significant resources to seek restitution from the perpetrator. Online auction sites may increase the percentages of the transactions they charge to offset some of these costs, and so the participants may wind up paying for these benefits themselves. But appropriate consumer protection and opportunities

\footnotetext{
139 See infra notes 195-200 and accompanying text for a discussion of what online auction sites are doing in this area.

140 See Finn et al., supra note 29, at 372; see also infra notes 201-05 and accompanying text (discussing what online auction sites are doing in this area).

${ }^{141}$ See Snyder, supra note 6, at 471; see also infra notes 206-09 and accompanying text (discussing of what online auction sites are doing in this area).

${ }^{142}$ See Finn et al., stipra note 29, at 372; see also supra notes 61-62.

${ }_{143}$ See Snyder, supra note 6, at 471.

${ }^{144}$ See NCL Report, supra note 17, at 5.
} 
for meaningful relief will increase consumer confidence in the online auction process, leading to increases in the numbers of auctions, with a greatly diminished threat of fraud. ${ }^{14,3}$

\section{B. Efforts to Combat Online Auction Fraud by Consumer Croups}

As publicity surrounding the prevalence of online auction fraud increases, in the absence of any meaningful protections undertaken by the online auction sites themselves, either of a voluntary or mandatory nature, new approaches for fighting fraud are being developed by consumer groups through consumer education efforts. ${ }^{146}$ Some of the consumer groups include the National Consumers League (NCL), ${ }^{1+7}$ the National Fraud Information Center (NFIC), ${ }^{1+8}$ Internet Fraud Watch (IFW), ${ }^{1+9}$ and Better Business Bureau Online. ${ }^{1.50}$

14. See Finn et al., supra note 29 , at 2.
14: See NCL Report, supra note 17 , at 3 .
14: "The National Consumers League, founded in 1899, is America"s pioneer consumer organization. Our mission is to identify, protect, represent, and advance the economic and social interests of consumers and workers. NCL is a private, nonprofit membership organization." NCL Warns Consumers, supra note 41, at 2. The NCL supports regulation to provide additional guidance for sellers, better tools for law enforcement agencies, and more effective penalties for perpetrators of Internet fraud. See NCL Report, supra note 17, at 5. Additionally, the NCL recommends permanent federal funding to train law enforcement in fraud investigation, prosecution, and to support non-profit organizations that collect and furnish data on online fraud to appropriate law enforcement agencies. Id.

${ }^{1+8}$ The NCL created the NFIC in 1992. The NFIC offers online services and a toll-free hotline for consumers to get advice about reporting suspected online fraud to law enforcement agencies. See About the National Fraud Information Center, at http:/ / www. fraud.org/ aboutnfic. htm last visited Mar, 9, 2002; see also Joel Dresang, Buyers Wamed After Complaints About eBay, Milwal kEF J. SEMTINE, Jan. 29, 1999, at 2; Weise, supra note 44; 1998 NCL Wams Consumers, supra note 4.

Ifi: The NCL created the Internet Fraud Watch as a companion program to the NFIC in 1996. See NCL Report, supra note 17, at 2; see also 1998 Internet Fraud Statistics, supra note 90; supra $39+4$ and accompanying text.

1.51 Better Business Bureau Online is a wholly owned subsidiary of the Council of Better Business Burcaus; its mission is to "promote trust and confidence in the Internet by encouraging sound and ethical online business practices and by providing information to ensure better educated online consumers." See http://www.bbbonline.org/consumer/ how.asp (last visited Mar. 9, 2002); see also Lucille M. Ponte, Throwing Good Money After Bad: Can Online Dispute Resolution (ODR) Really Deliver the Goods for the Unhappy Intemet Shopper?, 3 TUL. J. TIC.H. \& INTEL.. PRop. 5, 55, 56 n.2 2001). 
Consumer education is a critical component of any successful plan to eliminate online auction fraud. ${ }^{151}$ If consumer confidence in the Internet is diminished by the specter of fraud, the growth of ecommerce will likely decrease as well. ${ }^{152}$ While the services, programs, and information provided by these consumer groups have merit, they in no way require the online auction sites to conform their conduct to protect consumers. Thus, a need remains for a regulatory framework of consumer protection with effective avenues for relief. ${ }^{153}$ Online auction sites can simply opt out of any voluntary program, and their non-binding pledges to adhere, even to articulated standards, in the absence of meaningful financial sanctions for lapses, would be just that - non-binding. In the absence of financial liability for the online auction sites, the sites have little, if any, incentive to take steps toward the eradication of online auction fraud.

\section{Law Enforcement Efforts to Combat Online Auction Fraud}

Law enforcement authorities have become increasingly aware of the problems of online auction fraud. ${ }^{154}$ Many law enforcement

1.51 According to the FTC:

Law enforcement alone cannot stop the tide of fraudulent activity on the Internet. Meaningful consumer protection depends on education as well. Consumers must be given the tools they need to spot potentially fraudulent promotions, and businesses must be advised about how to comply with the law. The FTC's consumer and business education program uses the Internet to communicate anti-fraud and educational messages to reach vast numbers of people in creative and novel ways quickly, simply and at low cost. As more consumers and businesses come online, use of the Internet to disseminate information will grow.

FTC Statement on Intemet Fraud, supra note 4, at 11-12.

152 See Hetcher, supra note 73 , at 3.

${ }^{153}[\mathrm{E}]$-businesses argue that self-regulation is the only effective means to ensure ecommerce protection, arguing that those who "establish and use online systems" are best able to protect e-consumers and enforce their own rules. Yet, many doubt whether any e-commerce would limit self-interested actions or have the ability to regulate foreign or domestic deceptive trade practices. Relying upon market forces, e-commerce fraud is highly resistant to self-regulation and allows perpetrators to harm e-consumers even with content-filter mechanisms and non-governmental information campaigns. Voluntary self-regulation only would bind those who abide by such measures, for perpetrators have no interest in protecting e-consumer interests - thus necessitating governmental intervention.

Aguilar, supra note 132, at 10.

${ }^{154}$ Congress seems to be taking an interest in online auction fraud:

As Congress continues to examine ways to protect consumers online and combat cyber-scams, House Energy and Commerce Chairman Billy Tauzin (R-LA) and 
agencies are undertaking efforts to educate online auction participants on avoiding and reporting fraud. ${ }^{15.5}$ These agencies are pooling their resources to coordinate efforts to find and prosecute the perpetrators. These agencies include various state governments, ${ }^{156}$ the Securities and Exchange Commission, ${ }^{1.57}$ the U.S. Attorney's Office, ${ }^{158}$ and various combinations of law enforcement groups working together to launch initiatives aimed at ferreting out Internet fraud. ${ }^{159}$

Committee Member Rep. Heather Wilson (R-NM) have written several leading ecommerce companies seeking details on marketplace efforts to curb online auction fraud, specifically "shilling" (the practice of driving up bidding prices on behalf of the selleri.

Tauzin, Wilson Want Details on Shilling and Online Auction Fraud, at http://energycommerce. house.gov/107/news/06262001_304print.htm June 26, 2001). The letter requests information, among other things, concerning the types of fraudulent activities occurring on online auctions; the effect of the method of payment on the occurrence of fraud; the incidence of shill bidding; the effect of concealing seller and buyer identities; and the usefulness of feedback. Id.

${ }_{15 i}$ See NCL Report, supra note 17, at 7.

${ }_{1515}$ For example, the Texas Internet Bureau focuses on online consumer fraud, online child pornography, computer hacking, and other crimes. See Tom Fowler, State Forms Crime Team For Intemet; Huge Increases Expected in Online Consumer Fraud, Holsrov CHRON., Sept. 22, 2000 , at 1 .

1.5 The enforcement efforts of the Securities and Exchange Commission (SEC) with respect to online fraud involve approximately 2,000 lawyers, accountants, and analysts who examine eleven categories of fraud; the agency declined to describe these categories for fear that any definition of the categories, and details about the SEC's efforts, might prove counterproductive, hampering the agency's efforts by better informing the perpetrators. See Ellen L. Rosen, Savvy Investors Seek Out SEC to Stop Intemet Fraud, NAT'L L.J., Feb. 14, 2000, at B5. 1:i夕 The U.S. Attomey's office has a Criminal Division's Computer Crimes and Intellectual Property Section made up of twenty lawyers in Washington, D.C. who will assist the computer and telecommunications coordinators in each U.S. Attorney's office. See Rovella, supra note 36 .

The Department of Justice's computer crimes section started out as part of the General Litigation section in 1991; it was given full-fledged status in 1996, but with only five lawyers. Concurrently, the DOJ department created a network of federal prosecutors in each local office to prosecute local computer crimes, to stay up-to-date with the developing Internet law, and to serve as a clearing house for their co-workers. Id.

1.69 In February 2000, law enforcement and consumer protection agencies from twentyseven countries took part in "Internet Surf," a covert interagency program aimed at uncovering Internet fraud. The effort involved 150 international organizations, including the Commodities Futures Trading Commission (CFTC), the FTC, the SEC, the Postal Inspection Service and the DOJ. The CFTC examined about $300 \mathrm{Web}$ sites that promote a variety of investment schemes involving commodity futures and options and promise quick profits with little or no risk, and identified others for further investigation. See CFTC Takes 
The Department of Justice (DOJ) and the FTC have taken the lead among law enforcement entities in the fight against online fraud through consumer education. ${ }^{160}$ The DOJ, cognizant of the global nature of the Internet, participated in two programs to foster national coordination and cooperation among various law enforcement agencies. In February 1999, the DOJ established the Internet Fraud Initiative (IFI), a national initiative intended to provide a comprehensive approach to combating Internet fraud. ${ }^{161}$ The goals of the IFI are to ascertain the nature and scope of the online fraud problem, develop appropriate training for law enforcement officials, foster the development of investigative and analytical resources to identify and investigate online fraud, provide and facilitate coordination among various law enforcement groups, support and advise on Internet fraud prosecutions nationwide, and establish a program of public education and prevention. ${ }^{162}$

These goals are a good template for any effort to curb online auction fraud. Yet, without involving the online auction sites themselves and holding them financially liable for the fraud on their sites, these efforts will never succeed in doing more than closing the

Part In 'Intemet Surf To Root Out Fraud, SEC. LITIG. \& REG. REP., Apr. 19, 2000, at 3. The FTC, which investigates fraud claims based on deceptive trade practices, said it had received information on 1,600 Web sites from various national and international agencies. Id.; see also Rovella, supra note 36; Law Enforcers Target Intermet Auction Fraud, supra note 37; Law Enforcers Target Top 10, supra note 77.

160 "The FTC is the leader in both fighting fraud on the Internet and in using high-tech tools to detect and deter fraud and to educate consumers about online scams." Before the Subcomm. on Commerce, Trade and Consumer Protection of the House Enetgy and Commerce Comm., 107th Cong. 2 (2001), at http://www.ftc.gov/os/2001/11/muris011107.htm (last visited Mar. 9, 2002) (testimony of TimothyJ. Muris, Chairman of the Federal Trade Commission).

Recognizing that law enforcement alone cannot stem the tide of Internet auction fraud, the FTC has launched an ambitious education program directed at Internet auctions sites as well as auction participants. Most major and many smaller Internet auction websites have fraud prevention and detection programs, and many are working closely with law enforcement investigators when problem sellers are identified. In fact, starting in February, eBay-perhaps the largest and best-known of all Internet auction sites-will feed its fraud complaints directly to the [FTC] Consumer Sentinel data base.

Going, Going, Gone, supra note 42, at 2.

${ }^{161}$ Internet Fraud, supra note 16, at 6.

${ }^{162}$ Id. at $9-10$. 
proverbial barn door after the online auction fraud horse. Proactive prevention is necessary and must involve the online auction sites.

The second major effort by the DOJ is the Internet Fraud Complaint Center (IFCC), established in May 2000, in cooperation with the Federal Bureau of Investigation and the National White Collar Crime Center, a national support network funded by the DOJ. ${ }^{163}$ The IFCC also utilizes agents and analysts from the Internal Revenue Service and the U.S. Postal Inspection Service. ${ }^{164}$

The IFCC's primary mission is to address Internet fraud by facilitating the flow of information between law enforcement agencies and Internet fraud victims. ${ }^{16.5}$ The IFCC's key functions for federal, state, and local law enforcement agencies are to receive online complaints, analyze such complaints to identify particular schemes and general crime trends in Internet fraud, compile and refer potential Internet fraud schemes to law enforcement, and propose strategies for dealing with Internet criminals. ${ }^{16 i}$ As of November 3, 2000 , the IFCC web site had received more than 37.5 million visits and 19,490 complaints. ${ }^{167}$ The efforts of the IFCC are helpful but ultimately insufficient, as they deal only with online auction fraud that

16is The mission of the IFCC is:

[T] address fraud committed over the Internet. For victims of Intemet fraud, IFCG provides a convenient and easy-to-use reporting mechanism that alerts authorities of a suspected criminal or civil violation. For law enforcement and regulatory agencies at all levels, IFCC offers a central repository for complaints related to Internet fraud, works to quantify fraud patterns, and provides timely statistical data of current fraud trends.

IFCC, supra note 135; see Michael J. Sniffen, Govemment Web Site Encourages Reporting of Internet

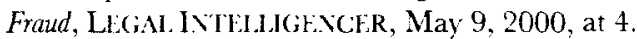

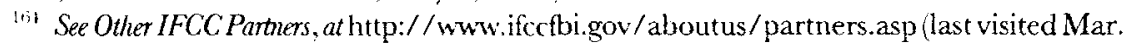
9, 2002.

${ }_{11,5}$ See Trends Report, uppra note 48, at 3; see also Consumer Information, at http://www. usdoj.gov/civil/od/con_info.htm ilast visited Mar. 9, 2002); New Report Reveals Latest Intemet Fraud Trends, Statistics, and Hotbeds, at http://www.nw3c.org/sixmonth_trendsreport.htm Mar. 6, 2001;.

11. See Internet Fraud, supra note 16, at 10; see also Sniffen, supra note 163.

${ }^{11 ;}$ See Trends Report, supra note 48, at 3; see also Fowler, supra note 156; Auctions Top List of Net Fraud, U.S.A. TODAY; Sept 3, 2000, at D1; Judith H. Dobrzynski, E-bidding Probed: FBI Opens Inestigation After Reports of Conspiracy to Run $L_{p}$ Bids on eBay Site, GAZETIL (MONTREAL), June 7, 2000, at D2; Statistics, at http://www.ifccfbigov/strategy/statistics.asp (last visited Mar. 9, 2002 !. 
has already happened, and do nothing to prevent online auction fraud.

The FTC raised concerns about the proliferation of fraud on the Internet and potential consumer protection problems resulting therefrom long before e-commerce boomed. ${ }^{168}$ As early as 1995, the FTC held public hearings to examine potential issues arising from technological innovations. ${ }^{169}$ The FTC's focus, then and now, has been on maintaining consumer confidence in the Internet. ${ }^{170}$

The FTC is involved in a comprehensive consumer and business education effort. ${ }^{171}$ As part of that effort, the FTC issued a Consumer Alert called "Going Shopping? Go Global! A Guide for e-Consumers" in March 2000, notifying prospective online consumers about the increasing incidence of online fraud, and offering tips for consumers who elect to participate in online commerce. ${ }^{172}$ Since the issuance of this Alert, potential auction participants and online auction sites have become more aware of the increasing incidence of online auction fraud. ${ }^{173}$ But the FTC has had only limited success in policing the online auctions, and, to date, the online auction sites have had no

\footnotetext{
168 See FTC Statement on Internet Fraud, supra note 4, at 13.

169 See FTC Statement on Consumer Protection, supra note 5, at 3; see also FTC Statement on Internet Fraud, supra note 4, at 2.

${ }^{170}$ The FTC believes "it is important to address Internet fraud now, before it discourages new consumers from going online and chokes off the impressive commercial growth now in progress and potential innovation on the Internet." FTC Statement on Intemet Fraud, supra note 4 , at 2 ; see also Snyder, supra note 6 , at 463.

171 According to the FTC,

More than 200 of the consumer and business publications produced by the FTC's

Bureau of Consumer Protection are available on the agency's Website in both text and .pdf format. Indeed, the growth in the number of our publications viewed online between 1996 and 1999 (140,000 vs. 2.5 million) tells the story of the Internet's coming of age as a mainstream medium and highlights the importance to any largescale dissemination effort. Those 2.5 million page views are in addition to the 6 million print publications the FTG distributes each year to organizations that disseminate them on the FTC's behalf.
}

FTC Statement on Intemet Fraud, supra note 4 , at 11-12.

${ }^{172}$ FTC tips to help consumers when they "go global" include: (1) know who you're dealing with; (2) know what you're buying; (3) understand the terms, conditions, and costs involved in the sale; (4) protect yourself when paying online; (5) look out for your privacy; (6) understand what recourse you have if you run into problems with your purchase; (7) get smart about e-commerce. Demand consumer-friendly policies and procedures. See FTC Consumer Alert, supra note 134.

${ }^{173}$ See Snyder, supra note 6, at 454. 
financial accountability for such fraud. In the absence of regulation requiring online auction sites to take financial responsibility for fraud on their sites, the FTC's only viable approach involves trying to prevent online auction fraud through consumer education efforts, and also stepping in after the fact, through prosecutions like Hare that hopefully will serve as a model for future online auction fraud prosecutions by the states.

\section{ONLINE AUCTION SITE RESPONSES TO ONLINE FRAUD}

Although the incidence of online auction fraud is rising, most of the public is not fully informed about the risks of Internet fraud. ${ }^{174}$ The online auction sites are aware of the increasing problem of online fraud, as they have been victimized by some hoaxes that have very publicly illustrated the potential for fraud on these sites. ${ }^{175}$ Yet the online auction sites decry the need for regulation, pointing to the selfpolicing mechanisms they undertake with, arguably, varying degrees of enthusiasm and even more varied results. ${ }^{176}$ The online auction

\section{See NCL Report, supra note 17, at 4.}

175 eBay had a very public example of the effects of the lack of regulation in bidding when in December, 1998, eBay asked Katie Couric of the "Today" show to auction off a jacket for charity after she and her co-workers signed it. Bids climbed to $\$ 200,000$, and then eBay learned, much to its embarrassment, that most of the bids were pranks. The high bid among legitimate bidders was 11,400 . See Beckett \& Swartz, supra note 58. After this public embarrassment, eBay began increasing its security measures. See Streitfeld, supra note 22. eBay claims the increases in security were not in response to the "Today" show mishap and had been planned for months. See Jon Swartz, eBay Tightens Security to Fight Against Fraud, S.F. ChroN., Jan. 16, 1999, at D1.

Items posted for sale on online auctions have purportedly included a guided missile, human body parts, a teenager's virginity, and votes in the 2000 presidential election, for which the bidding went as high as $\$ 10,100$. Rumored auctions of human babies for a high bid of $\$ 109,100$ and a human kidney for a high bid of $\$ 5.7$ million have proved to be hoaxes, but in the absence of appropriate regulation, auctions of items like this may not bc impossible to imagine. See BLVNELl, supra note 22, at 139; see also David Lazarus, eBay's Winning Bid, S.F. CHROX., Aug. 31, 2000, at C1; Steve Rubenstein, eBay Auction of Rare Stamp Probably an Intemet Hoax, S.F. Chrov., Sept. 29, 1999, at A16; Jathon Sapsford, Survey Says Online Fraud is Increasing as More Merchants Take Steps to Fight it, WALI. ST. J., at http://www.interactive.wsj.com/articles/SB97321100754533573.htm (Nov. 3, 2000) (on file with author); Shor Take: eBay Rulls Auction of User's Unbom Baby, C.NET NEWs.COM (Sept. 7, 1999), at http://news.cnet.com/news/0-1007-200-346836.html?tag=rltdnws.

176) Online trading communities face some unique challenges. Among them are finding creative cost effective means to protect users engaged in smaller transactions, providing convenient access to conventional forms of protection for users engagcd in 
sites are reluctant to undertake the financial costs of additional fraud prevention efforts, even as the numbers of reported online auction fraud cases continue to rise, casting doubt on the effectiveness of any particular measure or even the effectiveness of all such self-policing measures in the aggregate. ${ }^{177}$ But because the number of online auction participants continues to rise, the dilemma of how to provide greater security to online auction participants without incurring greater operating costs has been resolved by the online auction sites firmly in their favor. ${ }^{178}$

The online auction sites affirmatively and explicitly disclaim any responsibility for the risk of fraud on their sites, yet they oppose regulation, leaving the cost of fraud squarely on the victims. ${ }^{179}$ In

larger transactions, and developing effective means of dispute resolution. eBay has instituted three programs to address these concerns .... These innovative programs make it possible for eBay's users to more easily protect themselves against fraud, and resolve general disputes about products and services in a cost-effective manner.

eBay's Response to the FTC, supra note 28 , at 5 .

The creative array of consumer education and protection programs that eBay has developed respond to the challenges of the electronic marketplace. eBay is committed to improving its consumer education and protection programs to deal with new or unexpected consumer complaints. In the fast paced world of cyberspace, online firms such as eBay are better positioned to address consumer fraud, deception and misuse complaints than government regulatory agencies. eBay's recent efforts to enhance its consumer education and protection programs have been praised by a leading consumer group as an "innovative step to reduce the potential for problems with online auctions." Moreover, eBay has implemented those enhancements quickly and at minimal cost to its users.

Id. at 8 .

177 See supra notes $36-47$ and accompanying text.

178 eBay claims to realize the importance of consumer confidence in the online auction process. The most significant challenge that $\mathrm{eBay}$ has faced is improving its consumer protection programs to keep pace with the ingenuity of a small group who attempt to abuse the auction process. On its own initiative, eBay has instituted some of the most innovative and consumer friendly programs in the industry to protect its users from fraud, deception and misuse. eBay believes that its consumer education and protection programs are a model for other online person-to-person sites and other forms of e-commerce.

eBay's Response to the FTC, supra note 28, at 1; see also Finn et al., supra note 29, at 5 .

${ }^{179}$ While the language of eBay's lengthy User Agreement bears this out, the validity of such a broad disclaimer has been raised in California. See Don Bander, Buyers of Bogus Sports Items File Lawsuits Here Against eBay, SAN DIEgO UnION-TRIB., Apr. 21, 2000, at G-1. eBay has since amended its User Agreement to require Califomia residents to waive California Civil Code Section 1542, which provides: "A general release does not extend to claims which 
response to questions about the increase in online auction fraud, online auction sites first claim that the problem of fraud on their auction sites is overstated because fraud, as a mathematical matter, occurs in only a "tiny fraction" of their sales. ${ }^{180}$ Despite the technical validity of this mathematical argument, the actual numbers themselves are quite high, and the mathematical argument is likely of little comfort to online auction fraud victims. ${ }^{181}$

the creditor does not know or suspect to exist in his favor at the time of executing the release, which if known by him must have materially affected his settlement with the debtor." CAL. CIV. COIF § 1542 West 2001; see also eBay Lser Agrement, supra note 34, § 3.3; Lowry, supra note 83.

ist Of the 1.3 million online auction transactions completed each day, less than one percent result in reported fraud. "Percentage wise, Internet auction fraud is not as big a problem as it first appeared because it is based on sheer volume. However, this sheer volume still results in several thousand fraudulent transactions a year." Intemet Auction Fraud Report, supra note 11 , at 13.

eBay officials claim problems with fraud are extremely rare. with only one-tenth of one percent of its auctions involving fraud. See Swartz, supra note 175. That percentage may sound quite small, but since in the first quarter of 2000, eBay held 53.6 million auctions during which $\$ 1.15$ billion worth of goods were sold, the implication is that almost 50,000 eBay auctions involved fraud during that quarter alone. Id.

This number doesn't seem to trouble eBay. According to eBay's Associate General Counsel, Robert Chestnut, "You can look at it and say there were 50,000 cases of fraud but there are a lot of companies that would love to have only one-tenth of 1 percent of their customers have a problem." See Hansell \& Dobrzynski, supra note 70, at C-2. This "tiny fraction" of fraud complaints made to the site does not include the incidences of fraud that are reported elsewhere than to the online auction site itself, or incidents that are not reported at all. See Hendren, supra note 12.

'mi According to eBay's vice president Steve Westly: "Because we know the incidence of fraud is quite low, we're happy to stand behind the community on this. There's zero tolerance for fraud on the site." Robert Cribb, Intemet Auctioneer Fighting Fraud, TORONTO STAR, Jan. 21, 1999, at D-1; see also Carlton \& Tam, supra note 14 iquoting Rob Chestnut, eBay's Associate General Counsel in charge of fraud; Hansell \& Dobrzynski, supra note 70. Fifty thousand online auction participants might disagree. See Audri Lanford \& Jim Lanford, Online Auctions: Deal or Steal? at http://www:scambusters.com/Scambusters43.htm (Mar. 29, 2001 .

Commentators compare the burgeoning problem of fraud on online auctions with the problems associated with the pay-per-call technology using 900 numbers:

The same attributes that made pay-per-call services so attractive to fraudulent userslow start up costs and the potential for big profit - exist on the Internet today. The FTC and the FCC permitted the 900-number industry to attempt self-regulation and only upon its failure did strict regulations become necessary.

Snyder, supra note 6 , at 465.

If the Internet is to avoid a fate similar to that of the 900 -number industry, namely a 
The online auction sites themselves should take small comfort in this mathematical defense. Many of the online auction sites are publicly traded, so even though the actual number of reported fraud cases may seem reasonable in the context of the overall number of transactions, the public relations problems from a perception that an online auction site is a magnet for fraud could be devastating. If the perceived threat of fraud is too great, the users might elect not to participate. ${ }^{182}$ If users elect not to participate, the online auction sites will not earn commissions. Thus online auction sites have a financial incentive to make sure that fraud does not rise to that level, and so the sites will do the minimum necessary to keep users participating at a financially viable level to protect their profit margins. ${ }^{183}$ Any additional efforts on the part of the online auction sites will need to be financed by the sites from the revenue they earn from transactions on their sites, an option that is less than appealing to the online auction sites.

marked decrease in consumer confidence and participation, the FTC must address Internet fraud now. Self-regulation, whether of the 900 -number industry or of the online auction industry, will not be effective in preventing fraudulent users from abusing the consumer.

Id. at 471 .

18: In its lengthy user agreement, eBay makes it clear it does not vouch for the authenticity of any transaction. But as a publicly traded corporation with an astronomical market value of $\$ 19$ billion, it needs a good reputation-and as much new business as possible. The safer it is, the more likely to have both.

Streitfeld, supra note 22.

183 eBay does not seem prepared to abdicate all responsibility for fraud. See Snyder, supra note 6 , at 460 . Perhaps mindful of this, eBay CEO Meg Whitman acknowledged that "we [eBay] actually have a significant responsibility to make $\mathrm{eBay}$ as safe a site as possible to trade on. We also need to communicate that users have a responsibility as well." See Hendren, supra note 12. "eBay is acutely aware that online commerce will not continue to flourish if consumers lose confidence in the safety and security of their transactions." $e B a y$ 's Response to the FTC, supra note 28, at 1; see also Anderiesz, supra note 12. "eBay, like any consumer business, has a strong interest in making its shopping place as safe as possible; otherwise consumers will turn to competitors or reject online commerce sites altogether." eBay's Response to the FTC, supra note 28, at 1.

According to Internet analyst Vernon Keenan: "If eBay hadn't beefed up their security they would eventually have hit a wall. Any negative perception of safety on eBay would have turned off new users, especially as the demographics of the Internet move closer to the regular population." See Greg Miller, eBay Tightens Security for Net Auctions; Technology: Move By Company Comes After Recent Incidents of Fraud and Abuse Involving Users of Its Web Site, L.A. TIMLS, Jan. 16, 1999, at C2. 
While the online auction sites may not currently have legal liability for fraud on their sites, the sites arguably have a moral responsibility to keep their sites as free from fraud as possible. ${ }^{184}$ Since morality is not a line item on a financial statement, any appeal to the online auction sites to curb fraud must be mandatory in nature, with financial consequences for any failure to comply.

A second line of defense claimed by the online auction sites is that their efforts at self-policing are the most effective way to prevent online fraud. ${ }^{18 .}$ The sites vehemently oppose regulation, claiming that their consumer protection measures are sufficient to safeguard their users' interests and that the online auction sites themselves are in the best position to respond to issues of fraud, deception, and misuse, obviating any need for regulation. ${ }^{186}$

181 See Marilyn Geewax, Auction Sale Could Top $\$ 6$ Billion By Next Year, PAL.M BEACH PoST, at http://www.bearshop.net/Auctions. html (Oct. 25, 1999); see also Snyder, supra note 6, at 459.

${ }^{18 ;}$ In response to the FTC's request for comments, six companies "on the leading edge of the electronic commerce industry" argue "the U.S. government must continue to support industry self-regulation and encourage industry participants in consumer education to avoid stifling the growth and expansion of this dynamic medium." Comments of DoubleClick, Inc., GeoCities, Inktomi Corporation, Lycos, Inc., theglobe.com, inc., and Yahoo! Inc. in Response to the FTC Request for Academic Papers and Public Comments 1, at http://www.ftc.gov/bcp/icpw/comments/ wiley.htm Mar. 26, 1999!.

$e$ Bay recognizes that the integrity of its site and the confidence of its users is its most valuable commodity. It will continue to improve its consumer education and protection programs to meet the growing challenges of Internet commerce. eBay believes it can continue to meet these challenges without the stimulus of government regulation, and that other e-commerce firms should be encouraged to do likewise.

eBay's Response to the FTC, supra note 28 , at 9.

eBay has taken steps to decrease the incidence of fraud, adopting policies aimed at preventing and detecting fraud. According to Brad Handler, director of public policy for eBay, "eBay is a community that is working hard to create an environment of open, honest trade. It's incredibly difficult in the online and offline world to catch the dedicated criminal, but it doesn't mean we aren't trying." Handler goes on to say that eBay cannot "proactively monitor the site for illegal activity and that it relies on users to bring problems to its attention." See Beckett \& Swartz, supra note 58. eBay's company policy is to urge those who believe they are victims of fraud to report problems to eBay and then to local law enforcement authorities. See id,; see also Cribb, stura note 181; Finn et al., supra note 29, at 348.

${ }_{13 i}$ In comments made to the FTC, eBay claimed:

In the highly dynamic Internet marketplace, however, private firms such as eBay are in the best position to design and implement creative programs to respond to consumer complaints about fraud, deception and misuse. Therefore, both domestic 
The online auction sites worry that government regulation will stifle growth in the online commerce world. ${ }^{187}$ This self-serving argument is made at the expense of consumers who are left without any meaningful protection from online fraud. The online auction sites claim to be in the best position to effectuate necessary changes. While there may be some truth to this, the online auction sites seem either unable or unwilling to take the steps necessary to stem the tide of online fraud, or they are simply too slow in reacting to what they see by putting effective policies into place. ${ }^{188}$ The online auction sites want consumers to bear the risk of fraud, making the self-serving claim that buyers can protect themselves through a variety of completely voluntary tools and programs. ${ }^{189}$ The existing safeguards are insufficient, setting up programs that are costly in terms of the participants' time and money, and amount to essentially no protection unless the participants are willing to undertake the effort, and in some cases, the associated costs of the efforts. The increasing number of online auction fraud complaints demonstrate that these safeguards

and foreign government agencies should resist the temptation to impose regulations on online marketplaces and other forms of e-commerce in an effort to extend consumer protection to this new form of commerce. Effective consumer protection efforts are much more likely to emerge from industry self-regulation, "best practices" and dispute resolution than from government intervention. Regardless of how well meaning such intervention may be, it carries the serious risk of impeding the growth of the emerging e-commerce marketplace without providing meaningful benefits to consumers.

eBay's Response to the FTC, supra note 28, at 2; see also Ed Ritchie, Auction Sites Urged to Protect Users From Fraud, at http://www.auctionwatch.com/email/print.html?ret=/awdaily/ dailynews/march01/1-031901.html (Mar. 19, 2001); see also Wojcik, supra note 92, at 894.

${ }^{187}$ eBay recognizes and supports the role that consumer protection and law enforcement agencies have in investigating and prosecuting legitimate complaints of consumer fraud, whether such fraud occurs over the telephone, in person or in cyberspace. eBay is committed to working with such agencies to ensure that $\mathrm{eBay}$ 's users' rights are fully protected. Also, eBay encourages government agencies to develop creative ways to respond more quickly to consumer complaints about online transactions. Innovation is not, however, synonymous with regulation, and the government should proceed cautiously to ensure that its policies do not unnecessarily impede the growth of this new and dynamic marketplace.

eBay's Response to the FTC, supra note 28, at 8-9.

${ }^{188}$ See Snyder, supra note 6, at 470.

189 "eBay is committed to effective self-regulation and has been proactive in implementing programs and policies to empower and protect consumers." eBay's Response to the FTC, supra note 28 , at 1 . 
are ultimately ineffective, primarily because the participants are electing not to use them. ${ }^{190}$ These safeguards include voluntary user identification, escrowing funds, insurance, vetting offered goods, feedback, and other fraud prevention efforts.

\section{A. Voluntary Tools and Programs Available on Online Auction Sites}

\section{Voluntary User Identification}

Online auction participants can elect to participate in a voluntary identity verification process. Online auction sites have had problems finding a practical way to verify the personal identification information of their users. eBay had a verification program to check the basic address information of its users, but could not provide any additional assurance to its users about the reliability of potential trading partners. So, eBay created a program that lets consumers supply additional information including, Social Security number, driver's license number, and date of birth, to qualify for status as a "verified user." "191 The data is crosschecked with Equifax Secure Inc. for a fivedollar fee paid for by the participants. ${ }^{192}$ Once Equifax confirms the information as accurate, an "ID Verify" icon appears next to the user's name on the site. ${ }^{193}$ To protect users' privacy, eBay never sees this information and Equifax does not retain a record of information submitted through this program. ${ }^{19+}$ The identities of all buyers and sellers should be authenticated at no cost to the parties. This simply should be a cost of doing business for the online auction sites.

\footnotetext{
1:4 See Snyder, stipra note 6, at 465; see also supra notes 36-47 and accompanying text.

1:' See eBay's Response to the FTC, supra note 28, at 3-4; see also Snyder, supra note 6, at 461 n.43; Lowry, supra note 83; eBay Serices: Buying and Selling Tools: ID Verify Login, at hrtp://www.pages.ebay.com/services/buyandsell/idverify-login.html last visited Mar. 9, 2002); eBay Help: Basics: FAQ: Verified eBay Lser, at http://pages.ebay.com/help/basics/fverify.html last visited Mar. 9, 2002. To date, $\mathrm{eBay}$ is the only major auction site to offer this service. Yahoo! Auctions offers credit card verification as its attempt to verify identities. See Fahoo! General Help, at http://help.yahoo.com/help/us/auct/agen/agen-02.htm (last visited Jan. 7, 2002\%.

1:- See Miller, supra note 183; see also Lowry, supra note 83; Swartz, supra note 175.

1!: See eBay's Response to the F7G, supra note 28, at 3-4.

$1: 4$ Id.
} 


\section{Escrowing Funds}

Online auction participants can elect to use an escrow service, typically paying up to five percent of the total transaction value. ${ }^{195}$ The escrow fees are based on the amount of the transaction and the method of payment. ${ }^{196}$ A neutral third party holds the buyer's funds until the purchased item arrives and is found to be what was bid for, arriving in the condition described in the auction. ${ }^{197}$

The online auction sites often provide direct links to escrow services, constituting at least their implicit recommendation. ${ }^{198}$ But less than one percent of eBay customers use escrow services, regarding them as "expensive and cumbersome," 199 Of course, using an escrow service can delay the transaction. ${ }^{200}$ But without it, the entire burden of ensuring the merchandise bought and sold on an online auction site arrives in the promised condition is placed on the buyer. Instead, all payments above some de minimis amount should be processed through escrow agents paid for by the online auction sites. The sites should make favorable arrangements with independent escrow houses or undertake the service themselves.

\section{Insurance}

Online auction participants can elect to purchase insurance for certain auction transactions, but because the dollar amount of the typical online auction transaction is relatively low, insurers are not

195 See Internet Auctions: A Guide, supra note 10, at 2; see also Hendren, supra note 12.

196 See Geewax, supra note 184.

${ }^{197}$ See Tradenable, at http://www.tradenable.com/demo.html (last visited Mar. 9, 2002) for a step-by-step explanation of the escrow process; see also After the Auction-Using Escrow, at http://www.auctionwatch.com/email/print.html?ret=/awdaily/tipsandtactics/buyescrow.html; Hendren, supra note 12; Jerome, supra note 14.

${ }_{198}$ eBay's web site contains a more explicit recommendation: "Based on historical data, tradenable and eBay recommend that buyers and sellers use escrow services for transactions greater than $\$ 500$." See eBay Help: Community Standards: Escrow, at http://pages.ebay.com/ help/community/escrow.html (last visited Mar. 9, 2002).

199 See Snyder, supra note 6, at 461 n.42. According to a 2000 poll conducted by Harris Poll Online, $79 \%$ of the 2,196 respondents have never used an escrow service, $42 \%$ were not familiar with escrow services, $30 \%$ thought escrow services were unnecessary, and $19 \%$ did not want to pay the associated fees. See Online Auction Survey Questionnaire, 5-6, at http://www.nclnet.org/onlineauctions/auctionsurvey2001ques.htm Jan. 31, 2001) [hereinafter Qhestionnaire].

2(in) See Intermet Auctions: A Guide, supra note 10, at 2. 
rushing to get into this market. ${ }^{201}$ Those that are in the market are offering very limited benefits. ${ }^{202}$

eBay's "Fraud Protection Program" covers most offered items for up to $\$ 200$, less a $\$ 25$ deductible. Amazon.com's A-to-Z Guarantee reimburses up to $\$ 250$ on standard purchases and up to $\$ 2,500$ on Amazon.com Payment transactions, with a lifetime maximum of three claims. ${ }^{203}$ The program covers failure to receive merchandise paid for and receipt of merchandise that is materially different than represented. ${ }^{204}$ The link between the low dollar amount of the average online auction transaction and the low dollar amount of insurance currently offered to online auction participants will likely continue until the insurance companies raise the coverage limits. In the alternative, the online auction sites should offer insurance themselves, covering the full value of transactions, at some reasonable price. This would encourage users to purchase more expensive items without additional risk. ${ }^{20.5}$

\section{Vetting Offered Goods}

Online auction participants can elect to have some offered items authenticated. The seller nominally pays for the authentication, but the payment is typically reflected in an increase in the winning bid, due to the additional security. The online auction sites view the

\footnotetext{
sill See supra notes 50-51.

2n: See Margaret Kane, eBay Offers Security Measures, ZDNET News (Jan. 15, 1999), at http://www.zdnet.com/zdnn/stories/news/0\%2C.4586\%2C.2187917\%2C00.html (on file with the author); see also eBay Rerises User Agreement to Address Fraud, L.A. TimEs, Feb. 1, 1999, at C2; eBay's Response to the Federal Trade Commission, supra note 28, at 5; eBay Help: Community Standards: Insurance Process, at http://pages.ebay.com/help/community/ins-process.html (last visited Mar. 9, 2002).

2013 See Nancy L. Hix, Understanding Insurance, at http://www.auctionwatch.com/email/ print.html? ret=awdaily/tipsandtactics/buy-insurance2,html (last visited Mar. 9, 2002); see also Dave Baranowski, Supplemental Insurance: Is It Worth It?, at http://www.auctionwatch.com/ email/print.html?ret=awdaily/features/insurance/2.html (Apr. 27, 2001).

214 See eBay Help: Community Standards: Fraud Protection Program, at http://pages.ebay.com/ help/community/insurance.html (last visited Mar. 9, 2002); see also eBay Help: Community Standards: Fraud Protection Eligibility Checklist and Claims Process, at http://pages.ebay.com/help/community/ins-guide.html (last visited Mar. 9, 2002).

26, See infra note 253-55 and accompanying text for a discussion of the disputes examined in the eBay-Online Ombudsman Office program ranging from $\$ 1$ to $\$ 15,000$.
} 
transactions on their sites as private and do not vet the offerings or descriptions themselves. eBay's documentation contains prominent and unequivocal disclaimers, warning buyers that the auctioned items have not been verified by eBay, and that the buyer should beware. ${ }^{206}$ eBay has begun to provide third parties to authenticate certain offered items, at the option and expense of the sellers. ${ }^{207}$ The online auction sites will try to remove outright frauds, as they are legally obligated to take an item off their site within five days of receiving notice. ${ }^{208}$ But according to eBay, it will not remove an item unless the complainant can offer solid proof. ${ }^{209}$ Accordingly, there could be inauthentic items offered for sale simply because the proof was not "solid" enough in eBay's opinion.

The existence and quality of the offered merchandise should be represented to the buyer, or the buyer should have the opportunity to inspect the goods. It is unfair to require the buyer to assume all the risks of the condition of the merchandise without the opportunity to evaluate such condition.

${ }^{206}$ One eBay disclaimer reads:

NOTE: The opinions expressed by these evaluators are theirs alone. eBay does not examine the items listed on its site and does not have the expertise to evaluate items. eBay cannot guarantee the findings of these evaluators - authentication and grading are difficult, often subjective matters where the experts themselves occasionally disagree. Each of the companies listed on this page that provides authentication and/or grading services is an independent company, and eBay is not responsible in any way for any action, inaction, opinion, or service in connection with these companies. You should review the credentials of each company and use your own judgment before using a company's services.

eBay Help: Community Standards: Authentication and Grading: Overview, at http://pages.ebay.com/ help/community/auth-overview.html (last visited Mar. 9, 2002).

${ }^{207}$ For its more expensive items, eBay began offering a service called Great Collections in conjunction with Butterfields, a San Francisco auction house eBay purchased. Similarly, Amazon.com has partnered up with Sotheby's, using a network of art dealers approved by Sotheby's. According to Amazon.com, the majority of the high-end art on its site is sold through the Sotheby's section. See Hansell \& Dobrzynski, supra note 70; see also Scally, supra note 22. eBay's Great Collections program was disappointing in terms of volume and eBay substituted a re-tooled version called eBay Premier. See Cohen, supra note 22. eBay began using Collectors Universe and other third parties to authenticate certain products. See Joseph Menn, Technology: eBay Shares Surge as Fim Resolves Fraud Probe, L.A. TimES, Apr. 9, 1999, at C3.

${ }^{208}$ See Lowry, supra note 83 (quoting eBay general counsel Michael Jacobsen).

${ }^{209}$ See Hansell \& Dobrzynski, supra note 70; see also Streitfeld, supra note 22; The Bidding Game, supra note 12. 


\section{Feedback}

Online auction participants can elect to educate themselves about their auction counterparts, with varying degrees of reliability, by accessing the online auction sites' feedback forums. The online auction sites solicit feedback from their users, in the hopes of turning their customers into the equivalent of their police force. ${ }^{210}$ For example, if a user earns a low enough feedback rating, eBay will automatically suspend membership and the user will be unable to list or bid on items. ${ }^{211}$

But if the feedback area is not monitored, query how reliable such feedback actually is. What is there to stop a shill bidder from posting fraudulent feedback under another of his user names, showing himself in a favorable light? eBay expressly forbids shill bidding, but permits users more than one Internet name, making shill bidding less easy to detect by a cursory examination of bidders' user names. ${ }^{212}$

This purported self-policing mechanism could in fact turn out to be simply a mechanism for self-promotion and promotion of friends. Feedback comments must be related to actual transactions, as opposed to comments made about particular buyers or sellers in the abstract. $^{213}$

\footnotetext{
21" See eBay Senices: the Feedback Fonum, at http://pages.ebay.com/services/forum/ feedback.html last visited Mar. 9, 2002;.

The forum uses a numeric rating system, symbols and written comments to create a unique profile of its traders. Specifically, different color stars represent a user's "feedback rating;" that rating, which appears next to a user's name, shows how many positive, negative or neutral points the user has accumulated from other trading partners. Short written comments offer insights into how satisfied others have been with this trading partner.
}

eBay's Response to the FTC, supra note 28, at 4; see also Hansell \& Dobrzynski, supra note 70 . Of the 2,196 people surveyed in the Harris Poll Online, fifty-one percent always check information available about the seller on the auction site before bidding, and thirty-six percent usually check the information. See Questionnaire, supra note 199, at 2.

211 "You may not take any action that may undermine the integrity of the feedback system. If you earn a net feedback rating of -4 (minus four), your membership will be automatically suspended, and you will be unable to list or bid." eBay L'ser Agreement, supra note $34, \S 8$.

21.2 See The Bidding Game, supra note 12.

213 eBay adopted this approach last year. See eBay's Response to the FTC, supra note 28, at 5. 


\section{Other Fraud Prevention Efforts}

Online auction participants can elect to avail themselves of other programs aimed at preventing fraud. eBay has a Non-Paying Bidder Program designed to assist sellers who are having trouble collecting the auction proceeds from buyers; the program provides an appeals process for buyers who dispute their categorization as non-paying bidders. $^{214}$

eBay also operates its Safe Harbor program, a "comprehensive safety resource and protective arm." ${ }^{215}$ eBay claims to cooperate fully

214 The parties are encouraged to contact each other after the auction has ended. If a seller has not gotten a response from the successful bidder or feels the buyer will not pay, the seller must file a "Non-Paying Buyer Alert Form" within forty-five days after the end of the auction. Then eBay gets involved, sending an email to both parties, reminding the buyer to pay and disclosing the consequences of failing to pay. The consequences range from a warning to an indefinite suspension, depending on how many times this bidder has failed to pay. See eBay Help: Community Standards: Policies and Conduct: Non-Paying Bidder, at http://pages.ebay.com/help/community/npb.html (last visited Mar. 9, 2002).

${ }^{215}$ eBay Help: Community Standards: eBay Help: Rules and Safety, at http://pages.ebay.com/ help/community/index.html (last visited Mar. 9, 2002). eBay's SafeHarbor reporting system enables users to file fraud complaints at an early stage when it is still possible to settle them amicably. Specifically, when a user files a complaint with eBay's online fraud reporting service, eBay automatically sends an e-mail to the other trader involved. eBay clearly informs the trader about the complaint and gives him or her the opportunity to resolve the problem expeditiously. Also, eBay may inform the trader that failure to resolve the complaint may result in notification of the appropriate agencies by the complaining party.

The "SafeHarbor" program is divided into "dedicated departments" and "services for your protection." The dedicated departments are Fraud Protection and Prevention; Items that may not be allowed for sale; and Investigations. The "services for your protection" include Feedback Forum; Escrow; Fraud Protection Program; ID Verify; Authentication Services; Verified Rights Owner Program; and Dispute Resolutions. eBay can suspend or terminate the accounts of anyone it suspects of engaging in fraudulent activity in connection with the site. Id. "Without limiting any other remedies, eBay may suspend or terminate your account if we suspect that you (by conviction, settlement, insurance or escrow investigation, or otherwise) have engaged in fraudulent activity in connection with our site." eBay User Agreement, supra note 34, § 5.3.

Under its SafeHarbor program, eBay monitors and investigates conduct that undermines the integrity or faimess of the auction process. Such conduct may include abuse of its feedback forum process, bidding offenses, such as attempts to artificially raise the level of a bidding price (called shill bidding), selling offenses, such as failure to complete the transaction (called deadbeat bidders), contact information or identification offenses, such as providing patently false contact information and other offenses such as sending spam (unsolicited commercial e-mail). As part of its updated SafeHarbor initiative, eBay has strengthened its deadbeat bidder and shill bidder 
and promptly with law enforcement authorities to investigate, prosecute, and convict those engaged in fraud. ${ }^{216}$ eBay agreed in February 2000 to forward complaints about fraud on its site directly to the FTC. ${ }^{217}$ eBay is developing a database that identifies public consumer protection agencies in each state, and a procedure for forwarding its users' complaints about fraud directly to those agencies. $^{218}$

These nominally protective measures may in some cases raise the transaction costs of online auction sites to the participants, and thus may be of limited usefulness. ${ }^{219}$ All of these measures amount to essentially no protection unless the buyer is willing to voluntarily take advantage of them, and in some cases, bear the associated costs. ${ }^{220}$ This is neither an effective nor fair way to apportion the risk of fraud between the buyers, sellers, and online auction sites. A more appropriate approach to curbing online auction fraud would be to use regulation, enforcement, and consumer education, imposing financial liability on the online auction sites for any failure to follow the regulations. ${ }^{221}$

policies by adding tougher sanctions. Depending on the seriousness of the offense, eBay may warn offenders, or suspend them (temporarily or permanently) from the site. In appropriate cases, eBay may also notify the proper law enforcement authorities.

eBay's Response to the FTC, supra note 28 , at 6 .

2iis See Swartz, supra note 175.

217 See Fields, supra note 36; see also eBay to Submit User Complaints to FTC, L.A. TIMLs, Feb. 15,2000 , at C3.

218 See eBay's Response to the FTC, supra note 28 , at 6-7.

219 See Hetcher, supra note 73.

The existing safeguards and multiple proposed guidelines ultimately fail to attack the issue of online auction fraud at its source. The individual auction house's selfregulation attempts to solve the problem by setting up rarely used and cumbersome programs that are only initiated if the consumer chooses. The consumer protection groups have no real authority and only hope to educate the consuming public. The FTC has limited resources and cannot afford to prosecute every individual fraudulent online auction user. For obvious reasons, these three lines of defense ultimately fail to provide the consumers with the protection from fraud they should be entitled to expect. The most efficient method available for stopping online auction fraud is to establish liability with the one entity most capable of ending the fraudulent practice: the online auction house.

Snyder, supra note 6 , at 465.

Id. at $456-57$. 


\section{Alternative Dispute Resolution MEChanisms AVAILABLE TO VICTIMS OF ONLINE AUCTION FRAUD}

While defrauded online auction participants wait for lawmakers to hold the online auction sites financially responsible for the fraud on their sites, they can seek judicial relief. They can file lawsuits against their transaction counterparts, assuming they can find and obtain jurisdiction over such counterparts, and afford the cost of litigation. However, the Internet's capacity to circumvent and bypass geographic boundaries can create problems both in obtaining jurisdiction over unwilling defendants and in enforcing any judgments actually obtained. ${ }^{222}$ The defrauded participants may not have enough information on their counterparts to physically locate them. Because the average online auction transaction consumer loss is so low, traditional litigation may be cost-prohibitive. ${ }^{223}$

One condition for the continued growth of online commerce is that consumers have confidence that they will be able to obtain meaningful recourse in the event of an online commerce dispute. ${ }^{224}$ If the process to access such recourse is too complicated, or the cost of such

${ }^{222}$ Cyberspace differs from real space in at least three ways connected to the formation and resolution of disputes: (1) cyberspace has become a "community" complete with customs, norms and rules that differ from those in the real world; (2) in cyberspace, communication transcends time, space, and physical reality; and (3) cyberspace eliminates geographic boundaries. See Robert C. Bordone, Electronic Online Dispute Resolution: a Systems Approach -Potential, Problems, and a Proposal, 3 HaRv. Negot. L. Rev. 175, 177-81 (1998).

Jurisdictional challenges are just one of the many challenges cyberspace poses to governments. The authority of governments, which has traditionally been evident in a powerful and state-subsidized court and regulatory process, is less obvious online. Government has a role to play but it is not necessarily the same role government plays in offline consumer disputes. National authorities cannot claim sovereign regulatory authority over parts of cyberspace in the same way that they exercise authority over territories.

Ethan Katsh, Online ADR in Online Consumer Disputes 2, at http://www.ftc.gov/bcp/altdisresolution/comments/katsh.htm (Apr. 12, 2001); see also Summary of Public Workshop, June 6-7, 2000, Federal Trade Commission, Department of Commerce, at http://www.ftc.gov/bcp/altdisresolution/summary.htm (Nov. 2000) [hereinafter Summary of Public. Workshop]; Ponte, supra note 150, at 56 n.3. See John Rothchild, Protecting the Digital Consumer: The Limits of Cyberspace Utopianism, 74 IND. L.J. 893 (1999), for a discussion of jurisdiction over online conduct.

${ }^{223}$ See Ponte, supra note 150 , at 89.

${ }_{224}$ See Public Comments by the National Arbitration Fonum-Altermative Dispute Resolution for Consumer Transactions in the Borderless Online Marketplace 4, at http://www.ftc.gov/bcp/altdisreolution/ comments/anderson.htm (Apr. 18, 2000). 
recourse exceeds the amount in controversy, the aggrieved party has no incentive to seek such recourse. The continually increasing volume of e-commerce results in an increasing volume of disputes. If traditional litigation is not a feasible option to settle such disputes, defrauded consumers must seek out other avenues of relief. ${ }^{225}$

Arguably, in response to the lack of meaningful regulatory protection and opportunities for judicial relief through traditional litigation for defrauded online auction participants, a number of online alternative dispute resolution (ADR) sites have cropped up on the Internet. For a sampling of current online $\mathrm{ADR}$ projects and websites, see Appendix A attached hereto. ${ }^{226}$ These sites seek to provide a mechanism for resolution of disputes arising from online transactions. Most of these sites are no more than a few years old, and are, for the most part, for-profit enterprises. ${ }^{227}$ There are a few exceptions, such as the early online ADR projects that were not-forprofit sites run by universities, but they are the distinct minority. ${ }^{228}$ The targeted audience of the various online ADR sites range from defrauded consumers to big corporations and their customers. Likewise, the services of the online ADR sites range from simply providing a forum for participants to air their views of sellers all the way to providing binding resolution of disputes. ${ }^{229}$

225 See M. Ethan Katsh, Dispute Resolution in Cyberspace, 28 CONN. L. RFV. 953 (1996); see also Katsh, supra note 222, at 3; Ethan Katsh et al., E-Commerce, E-Disputes, and E-Dispute Resolution: In the Shadow of "eBay Law", 15 OHIO ST. J. ON DISP. RESOL. 705, 725 (2000); Ponte, supra note 150 , at 57,91 .

${ }^{2963}$ For a complete list of such sites, see Current Online ADR Projects and Web Sites, at http://www.ombuds.org/center/onlineadr.htm (Apr. 10, 2001); see also Out of Court Settlement of Disputes Concerning e-commerce Consumer Transactions: An Inventory of Current Approaches, at http://www.oecd.org/dsti/sti/it/secur/act/online_trust/ICCInventory.doc (last visited Mar. 9, 2002).

See Katsh, supra note 222.

$22:$ The University of Massachusetts's Center for Information Technology initiated The Online Ombuds Office in May 1996, to provide mediation for disputes arising on the Internet. See Professor Ethan Katsh's Response to the Federal Trade Commission's Request for Academic Papers and Public Comments 2, at http://www/ftc.gov/bcp/icpw/comments/ethankatsh.htm (last visited Mar. 9, 2002); see also Ponte, supra note 150, at 65.

"wn' See Lan Q. Hang, Online Dispute Resolution Systems: The Future of Cyberspace Law, 41 SANTA CIARA L. REY. 837, 845-50 (2001). 
ADR refers generally to various out-of-court methods for resolving disputes, including negotiation, mediation, and arbitration. ${ }^{230}$ All of these processes are less formal than litigation, and are typically also faster and less expensive. ${ }^{231}$ These traditional forms of ADR are fairly easily adaptable to the online arena, utilizing the unique characteristics of the Internet to settle online disputes. ${ }^{232}$ Online ADR takes advantage of the Internet in three ways: (1) when online, one can handle matters that previously required physical presence at a distance; (2) when online, one can handle matters quickly, if not instantaneously, that might have been cumbersome or, in fact, impossible, previously; and (3) when online, one acquires information-processing capabilities beyond those of human capabilities. $^{233}$

Online ADR processes fall into two primary categories: automated processes and neutral-managed processes. ${ }^{234}$ The automated processes are appropriate for disputes involving parties whose

${ }^{230}$ See Ethan Katsh, Online Dispute Resolution: Some Lessons Leamed From the E-Commerce Revolution, 28 N. KY. L. REV. 810,812 (2001),

${ }^{231}$ Negotiation is a consensual bargaining process aimed at achieving a mutually acceptable settlement, using direct communication between the parties to a dispute, typically with no third parties involved. See Public Comments by WebMediate-Altemative Dispute Resolution for Consumer Transactions in the Borderless Online Marketplace 2, at http://www.ftc.gov/bcp/ altdisresolution/comments/bakerryan.pdf (Spring 2000) [hereinafter Public Comments by WebMediate]. Mediation is a process in which a neutral third party mediator assists the parties in finding their own solution to the dispute. See Hang, supra note 229, at 842 . The process tends to be voluntary, informal, flexible, and private. See id.; see also Frequently Asked Questions, at http://www.webmediate.com/faq.html (last visited Mar. 9, 2002) [hereinafter WebMediate FAQ]. The mediator does not make decisions for the parties. Rather, she helps them communicate and find common ground. See Services: What is ADR? 1, at http://www.onlineresolution.com/whatisadr.cfm (last visited Mar. 9, 2002). Arbitration is more formal than either negotiation or mediation. The parties select an arbitrator, typically an impartial professional with some expertise in the area of the dispute, to hear presentations from the parties and render a decision. Id. Arbitration cases involve choice-of-law issues, and are typically governed by a specified set of procedural rules. See Public Comments by WebMediate, supra note 231, at 2. Arbitration can be binding or non-binding. Id.

232 "In the existing and currently functioning arena of domain names, arbitration has been workable, in insurance claims disputes a totally automated negotiation process has been in growing use, and in the online auction context, mediation may be preferred." Katsh, supra note 222 , at 2.

${ }^{233}$ See Katsh, supra note 230, at 816-17.

234 See Public Comments by WebMediate, supra note 231, at 5. 
interests can be easily quantified. ${ }^{23 j}$ The process is typically managed by a computer using "blind bidding" whereby the parties to the dispute have an online forum to submit settlement offers. If the settlement offers fall within some pre-determined and pre-approved range, the computer program plays arbitrator, settling the dispute, with the parties splitting any difference. The entire process occurs online; the parties are given password-protected access to their dispute negotiations. ${ }^{236}$ If the two parties' bids never get close enough, they will never know what the other side bid. ${ }^{237}$ The online ADR firms are compensated by a percentage of the settlement. ${ }^{238}$

In order for an automated process to resolve consumer disputes successfully, the parties must be in agreement about the basic facts, including who is the injured party. Also, money damages alone must be able to make the injured party whole. The only item to be resolved by the process is the actual amount of the damages to be awarded. If these conditions are satisfied, query why the parties would pay additional sums to a third party to come up with the dollar amount of the damages rather than hashing it out themselves. ${ }^{239}$ Perhaps it may be worth the cost of blind bidding to not reveal their bids unless they are accepted.

The other category of online ADR, the neutral-managed processes, offers the parties to a dispute a variety of ADR services, with the benefits of the Internet along with access to trained neutral professionals to assist in resolving the dispute. ${ }^{240}$ The neutral professionals can monitor the settlement negotiations and participate as negotiators, mediators, or arbitrators, using the Internet to reduce overhead costs and time delays. ${ }^{241}$ This form of online ADR is appropriate when the conditions for automated blind bidding are not met. The parties may disagree on the quality, authenticity, or condition of the offered item, or on some other term in their agreement. ${ }^{242}$ In such

Examples of this form of online ADR include Cybersettle.com, clickNsettle.com, and Settlesmart.com. See Ponte, supra note 150, at 66 nn.44-46.

236 See Summary of Public Workshop, supra note 222, at 5.

${ }_{237}$ See Frequenily Asked Questions, at http://www.wecansettle.com/pages/faqs.html (last visited Mar. 9, 2002).

See WebMediate FAQ supra note 231.

239 See Ponte, supra note 150 , at $66 \mathrm{nn} .43-47$.

21) See Public Comments by WebMediate, supra note 231, at 6 .

${ }^{2+1}$ Id.

$2+2$ See Ponte, supra note 150 , at 70 . 
cases, the neutral third party tries to negotiate a mutually satisfactory result. $^{243}$

The benefits of online ADR include easy accessibility, in that online ADR is available on demand and at the parties' convenience, without regard to traditional business hours. ${ }^{244}$ Also, online ADR can be more convenient than traditional ADR in that participants do not need to travel to resolve their disputes. ${ }^{245}$ Online ADR is typically much less expensive than litigation or even traditional ADR. ${ }^{246}$ Additionally, online ADR sidesteps the jurisdictional issues inherent in many online disputes. ${ }^{247}$ Online ADR also can be conducted on a large scale. There are no comprehensive statistics on online ADR use, but SquareTrade claims to handle over 12,000 claims per month, ${ }^{248}$ and Cybersettle claims to have helped its clients settle over $\$ 50$ million in claims. ${ }^{249}$

Online ADR is not a panacea, however. The parties must have access to any necessary software and must have some degree of proficiency with computers. ${ }^{250}$ There are security and confidentiality concerns inherent in using the Internet. ${ }^{251}$ Finally, the parties must agree to submit to the process and to be bound by its outcome. Online ADR will be of no use if one of the parties elects not to participate, or participates but then does not honor the resolution generated by the process. This may be the outcome in an online auction fraud case, and if so, the availability of low cost, accessible online ADR services will then be of no use to the defrauded party who will have to rely on the protections and avenues of relief provided by lawmakers, which are currently insufficient.

Various law enforcement officials and companies interested in ecommerce are working together to craft a workable online ADR system, perhaps to ease public concern about preventing and

\footnotetext{
${ }^{243}$ Examples of this form of online ADR include SquareTrade and Internet Neutral. Id.

244 See Hang, supra note 229, at 854.

245 Id.

${ }^{246} \mathrm{Id}$.

${ }^{247} I d$.

${ }^{248}$ See Square Trade Builds Trust, at http://www.squaretrade.com/cnt/jsp/abt/aboutus.jsp; jsessionid $=$ fo0oabey 31 ?vhostid=tomcat $3 \&$ st (last visited Mar. 9, 2002).

${ }^{249}$ See Cybersettle-About Us, at http://www.cybersettle.com/about/ (last visited Jan. 7, 2002).

25i) See Hang, supra note 229, at 859.

${ }^{251} I d$.
} 
prosecuting online fraud. ${ }^{252}$ Even the online auction sites have shown an interest in online ADR. During the spring of 1999, eBay joined with the Online Ombuds Office (OOO) at the University of Massachusetts to form a pilot program for its dissatisfied online auction customers. ${ }^{2 \cdot 3}$ Almost 150 disputes arising out of online auctions were mediated in the two-week pilot period. ${ }^{2.54}$ Despite the fact that the average online auction transaction is $\$ 478$, the value of the disputes mediated ranged from $\$ 1$ to $\$ 15,000 .^{2.55}$

InJune 2000, the FTC and the Department of Commerce sponsored a public workshop entitled "Alternative Dispute Resolution for Consumer Transactions." The participants included representatives from academia, consumer groups, industry, and government. See Summary of Public Workshop, supra note 222. The participants "examined existing and developing ADR programs, incentives and disincentives to use ADR, how to make ADR fair and effective, and the role of stakeholders, including consumers, businesses and governments, in developing and implementing ADR programs." Id. The participants recommended cooperation in the following areas: (1) finding global solutions to address global transactions; (2) pursuing technological innovations; 3) pursuing multiple ADR programs; (4) ensuring fairmess and effectiveness of ADR programs; (5) consumer and business education; and (6) action against fraudulent and deceptive practices related to ADR. Id. at 3. The participants focused primarily on the proposal for online ADR:

The goal is to resolve [e-commerce disputes] in a manner that reflects that the monetary value of these disputes, while important to individual consumers, is often small in amount. Therefore, traditional court-based solutions, including small claims courts, particularly for people who live in different countries, are by and large impractical.

Id. In addition, conferences and workshops on online ADR were held by the European Union, Hague Conference on Private International Law, Organization for Economic Cooperation and Development, Global Business Dialogue, and the World Intellectual Property Organization. See Katsh, supra note 230, at 813-14. In addition, the American Bar Association Section on Dispute Resolution, the CPR Institute of Dispute Resolution, and SPIDR all held sessions on online ADR at their respective annual meetings. Id.

${ }_{22: 3}$ See Ethan Katsh \& Janet Rifkin, Online Dispute Resolution: Introduction 1, at http://www.disputes.net/cyberweek2001/OnlineDisputeResolutionIntro.htm (last visited Mar. 9, 2002); see also http://www.disputes.net/cyberweek2000/ebay/ebayintro.htm (last visited Mar. 9, 2002).

231 See Online ADR, supra note 223. A link was placed on the eBay customer service page, telling users that they could get assistance with transaction-related disputes by clicking on a link and filling out a complaint form. eBay did nothing to publicize the service, and the customer service page was two levels from eBay's home page. Nonetheless, in a two-week period, 225 users filed complaints. See Katsh, et al, supra note 225, at 709 . Of these 225 complaints, the $O O O$ attempted mediation with only 144. Id. at 712 .

See Katsh \& Rifkin, supra note 253, at 1; see also supra note 50. 
At the completion of the pilot program with the OOO, eBay joined with Square Trade in a similar program to provide mediation services for its dissatisfied users. ${ }^{256}$ The eBay-SquareTrade pilot program provided free online dispute resolution services on items sold for at least $\$ 100$ on eBay. ${ }^{2.57}$ The pilot was illustrative for the two companies in terms of creating a greater understanding of the issues involved in online ADR. ${ }^{258}$ Since the end of the pilot program in June 2000, eBay users can utilize Square'Trade's Online Dispute Resolution to settle disputes independently without a mediator using SquareTrade's Web-based Direct Negotiation Tool, ${ }^{259}$ or they can use a "SquareTrade Neutral" mediator or arbitrator. ${ }^{260}$ SquareTrade's Direct Negotiation service is free. ${ }^{261}$ Using a SquareTrade mediator

${ }^{256}$ SquareTrade is an online ADR site that, among other services, provides e-commerce auction disputes through direct negotiation and mediation. See http://www.squaretrade.com (last visited Mar. 9, 2002).

According to eBay's website in July 1999: "SquareTrade is offering its online dispute resolution service to eBay users for FREE for those items that sell for at least $\$ 100$ during this pilot period." See Dispute Resolution Overview: Who Can Use This Service and How Much Does it Cast?, at http://pages.ebay.com/services/buyandsell/disputeres.html (last visited July 17, 2000) (original emphasis in bold) (on file with author).

257 The pilot period ran until June 2000. See Claire Barliant, Bound To Happen: E-Commerce Disputes Spawn ClickNsettle, Fulton COUNTY DaII.Y REP., June 23, 2000.

258 According to Steve Abernathy, CEO and founder of Square Trade:

What we've learned in our pilot with eBay is how to recognize and list common types of disputes that occur, alongside their outcomes. We're essentially building case law for online commerce. We're also taking suggestions from online mediators and adding that to the list of solutions to different kinds of problems.

Jenny Oh, Fair and Square, THE INDUSTRY STANDARD, at http://www.thestandard. com/article/0,1902,18725,00.html (Oct. 2, 2000).

${ }^{259}$ Direct negotiation on SquareTrade involves only the parties to the dispute; they negotiate through password-protected pages without a mediator. See Help-Dispute Resolution: Direct Negotiation, at http://www.squaretrade.com/cnt/jsp/hlp/help_odr_case_file.jsp; jsessionid=vh3pwa70d2:vhost (last visited Mar. 9, 2002).

${ }^{260}$ See Help-Dispute Resolution: Case Filing and Responding, at http://www.squaretrade. $\mathrm{com} / \mathrm{cnt} / \mathrm{jsp} / \mathrm{hl} / \mathrm{hel}$ _odr_case.jsp?vhostid=tomcat $1 \&$ stmp=-squaretrade (last visited Mar. $9,2002)$.

261 According to SquareTrade, more than eighty percent of cases are resolved with the use of the Direct Negotiation technology, without requiring the services of a SquareTrade Neutral (mediator or arbitrator). See Help-Dispute Resolution: Mediation, at http://www.square trade.com/cntl/jsp/hlp/help_odr_med.jsp?vhostid=tomcat2\&stmp=squaretrade (last visited Mar. 9, 2002). 
will cost the participants fifteen dollars; the remainder of the fee is paid by eBay. ${ }^{262}$

Online ADR, like any new technology, may be disruptive to those comfortable with the offline ADR processes. But online ADR, either as a totally new approach, or as a modification to existing ADR processes, is becoming much harder to ignore. ${ }^{263}$ In the absence of meaningful protection for defrauded online auction participants through regulation and enforcement, the need for ADR will likely grow dramatically. The judicial system does not have the resources or specialized knowledge necessary to handle a flood of Internetrelated lawsuits, with their complicated jurisdictional issues. Online $\mathrm{ADR}$ is a logical approach to resolving Internet-based disputes without resorting to litigation. Online ADR services must be easy to use, convenient, and must give the users a sense of security and confidentiality in and about the process. ${ }^{264}$ Because the average consumer loss on an online auction transaction is so low, the cost of online ADR services will need to be correspondingly low enough that disputants will avail themselves of the services. This may require some funding by the online auction sites themselves, as a way to compensate those users who were victims of fraud on their sites. ${ }^{26.5}$

\section{CONCLUSION}

An aggrieved party using an online auction site, which specifically disclaims responsibility for determining the authenticity of sellers' merchandise, can prevail legally against the seller only in the event that the seller makes materially false statements in describing the auctioned item. ${ }^{266}$ This is age-old common law, and remains sound today. But the online auction sites that facilitate the fraudulent transactions simply by providing the forum for the exchange should not have immunity from liability for such fraud. Under current law,

\footnotetext{
Id.

sis See Katsh \& Rifkin, supra note 253, at 2.

stit See Hang, supra note 229, at 862.

245 See Ponte, supra note 150 , at 91.

2ici See Dobrzynski, supra note 103.
} 
a fraud cause of action cannot be sustained against an online auction site. ${ }^{267}$ But as technology changes, so too should the law. ${ }^{268}$

The online auction sites claim they are merely providing the meeting place for independent parties who assume all the risk of any transaction the site makes possible. As such, the online auction sites claim immunity from any responsibility for fraud occurring on the very sites over which they have exclusive control. ${ }^{269}$

The FTG should use its substantial regulatory authority to craft binding regulations for online auction sites. A starting point for the regulations could be to build on the steps that some of the online auction sites are already undertaking, albeit with varying degrees of enthusiasm. The regulations should include ideas such as authenticating participants' identities, limiting the number of user names per participant, verifying the creditworthiness of participants, providing free escrow services, offering insurance for the full amount of transactions, offering authentication of items for sale, and establishing mandatory record-keeping provisions, along with any other steps necessary to provide the highest level of consumer protection possible. Any failure to comply with the regulations should result in financial liability to the online auction site. Consumer confidence is the key to

267 "Attorney [Brian] Brokate [who has a full time staff tracking online knockoffs in luxury goods] concedes that online auctioneers probably can't be held legally responsible unless they're informed of a specific fraud and refuse to act. eBay has been quick to help so far, he said." See Hendren, supra note 12.

${ }^{268}$ As legislators at both the national and local levels attempt to create regulatory schemes for Internet commerce, and as both state and federal courts adjudicate an increasing number of Internet-based disputes, the importance of better understanding the implications of regulating the Internet as interstate commerce becomes paramount. Glearly, the Internet is evolving and developing at a much more rapid pace than any other mechanism of commerce. Most scholars, legislators, and practitioners would agree that the Internet has not reached its final form. Regulators must be careful not to arrest this evolution. Yet, a proper regulatory scheme poses the opportunity to make the Internet more stable, to increase confidence in its ability to accommodate commercial transactions, and to reduce uncertainty about liability for Internet-based activities. Such a scheme would likely accelerate, rather than arrest, the growth of electronic commerce and Internet-based technology. The path towards such a scheme will necessarily require us to answer questions about how much regulation is appropriate, who should regulate, and how.

Charles R. Topping, The Suff is Up, But Who Owns the Beach? - Who Should Regulate Commerce on the Intemet?, 13 NOTRE DAMF J.L. ETHICS \& PUB. POI'Y 179, 194-95 (1999).

${ }^{2653}$ See Finn et al., supra note 29, at 352. 
636 / Vol. 39 / American Business Law foumal

realizing the potential for growth in the Internet. Online auction sites should not be permitted to reach out for their percentage of the transactions with one hand, while at the same time covering their eyes to the fraud on their own sites with the other hand. 


\section{APPENDIX: ONLINE ADR PROJECTS AND WEBSITES}

The following is a sampling of current online ADR projects and websites, with brief descriptions of the services offered. ${ }^{270}$

The targeted audiences of these online ADR sites range from defrauded consumers to big corporations and their customers and their services range from simply providing a forum for participants to air their views of sellers all the way to providing binding resolutions. ${ }^{271}$ Some of the sites may be appropriate for online auction disputes.

- 123Settle.com: in association with ARC-Alternate Resolution Centers, this site provides a "full service on-line settlement program" including facilitated negotiation, arbitration, and evaluation services using blind bidding, which involves the confidential submission of offers and demands which are compared by the 123Settle program. ${ }^{272}$

- Allsettle.com: this site provides double-blind negotiation to settle almost any kind of insurance claim. Upon settlement, the insurance company involved pays a $\$ 200$ fee. $^{273}$

- BBB Dispute Resolution: this site provides national dispute resolution services, including conciliation, mediation, and arbitration. ${ }^{274}$ Individual Better Business Bureaus ("BBB") operate their own dispute resolution programs for companies and customers in their areas. ${ }^{275}$ More than 100 BBBs participate in BBB CARE, a standardized dispute settlement program coordinated by the Council of Better Business Bureaus. ${ }^{276}$

- The Chartered Institute of Arbitrators: this site offers mediation, arbitration, and online consumer arbitration in the

${ }^{227}$ For a complete list of such sites, see Current Online ADR Projects and Web Sites, at http://www.ombuds.org/center/onlineadr.htm (Apr. 10, 2001); see also Out of Court Settlement of Disputes Conceming e-commerce Consumer Transactions: An Inventory of Current Approaches, at http://www.oecd.org/dsti/sti/it/secur/act/online_trust/ICCInventory.doc (last visited Mar. 9, 2002) [hereinafter ICC Inventory].

${ }^{271}$ See Hang, supra note 229.

${ }^{272} \mathrm{Http}: / /$ www. 123settle.com (last visited Aug. 19, 2001) (on file with the author).

${ }^{273}$ See http://www.allsettle.com/faq.htm (last visited Mar. 9, 2002).

${ }^{274}$ See http://www.bbb.org/complaints/aboutResolution.asp (last visited Mar. 9, 2002).

${ }^{275}$ Id.

${ }^{270} \mathrm{Id}$. 
United Kingdom. ${ }^{277}$

- ClaimResolver: this site seeks to "enable all parties to reduce the time and cost of resolving claims by creating and implementing the most effective and efficient Internet-based dispute resolution programs available in the market." ${ }^{\prime 278}$ The service is appropriate for claims "where settlement will be based on a dollar payment."279 The parties seek settlement using any of the sites programs: Offer/Demand Protocol, Maximum/Minimum Option, Finding Negotiation Parameters, Quick Settlement Program and MultiDefendant/Aggregate Settlement. ${ }^{280}$ The standard fee to enroll a claim is $\$ 35$. If the program generates a settlement under $\$ 10,000$, a "success fee" of $\$ 250$ is charged to the parties; if the program generates a settlement of $\$ 10,000$ or more, the "success fee" is $\$ 350 .^{281}$

- ClickNsettle: this negotiation site started in June 1999 with the objective of offering "online computer assisted method for settling dispute by giving its users the power to negotiate settlements with total confidentiality." ${ }^{282}$ The negotiation service deals with cases involving every area of law. Users agree to be legally bound by any settlement reached through ClickNsettle, and any such settlement is a bar to any further claim or cause of action arising form the same facts. ${ }^{283}$ The site provides Web-enabled blind bidding negotiation as well as in-person, video-conferenced, or paper arbitration and mediation. ${ }^{28+}$ Cases that do not settle during online negotiations can be automatically submitted to the site's inperson division for arbitration or mediation. ${ }^{285}$ The site has worked with numerous web sites and e-commerce providers to

\footnotetext{
77 See http://www.arbitrators.orb/Services/dispute_resolution_services.htm (last visited Mar. 9, 2002).

${ }^{278} \mathrm{http} / /$ www.claimresolver.com/ecAbout.nsf/(StaticContents)/About?OpenDocument last visited Mar. 9, 2002!

int $I d$.

$I d$.

${ }^{281}$ http://www.claimresolver.com/ec.About.nsf/(StaticContents)/Fees?OpenDocument (last visited Mar. 9, 2002).

ICA: Inventory, supra note 270 , at 6 .

${ }_{2 R 3} I d$. at 8.

2kt See http://www.clicknsettle.com/why_cns.cfm (last visited Mar. 9, 2002).

28.7. See http://www.clicknsettle.com/online_benefits.cfm (last visited Mar. 9, 2002).
} 
develop online ADR programs tailored to the providers' needs. ${ }^{286}$

- Cybersettle: this negotiation site started in August 1998, with the objective of providing "confidential, automated, online dispute resolution for users." 287 The site claims to be the first company "to offer an online, computer-assisted method for settling insurance claims" and that their "patent-pending, blind-bid system helps users resolve any monetary dispute with unprecedented speed and total confidentiality." "288 "The site has helped settle over $\$ 50,000,000$ in claims and has over 60,000 current users with 475 insurance companies using the service. ${ }^{289}$ Settlements obtained through Cybersettle are binding on the parties. ${ }^{290}$ The site charges a "success fee" ranging from $\$ 100$ to $\$ 1,000$, depending on the size of the settlement. ${ }^{29}$

- Electronic Consumer Dispute Resolution (ECODIR): this project targeted the "establishment of an innovative service for the prevention and the resolution of consumer conflicts arising in cyberspace. It is aimed at offering to European consumers an efficient, quick and affordable mechanism to solve their disputes with on-line sellers." ${ }^{292}$ The three-part process includes negotiation, mediation, and recommendation the neutral mediator. ${ }^{293}$

- i-Courthouse: this arbitration site provides on-line adjudication and dispute evaluation and resolution. ${ }^{294}$ Results are enforceable by agreement of the parties. ${ }^{295}$

- IntellicOURT: this site provides online mediation and both binding and non-binding arbitration services through ArbitrationSolutions. ${ }^{296}$

\footnotetext{
${ }^{286}$ See http://www.clicknsettle.com/sol_ecommerce.cfm (last visited Mar. 9, 2002).

287 ICC Inventory, supra note 270, at 12.

${ }^{288}$ http://www.cybersettle.com/about (last visited Mar. 9, 2002).

${ }^{289} \mathrm{Id}$.

${ }^{290}$ See Department of Commerce and Federal Trade Commission's foint Workshop on Alternative Dispute Resalution for Online Consumer Transactions 3, at http://www.ftc.gov/bcp/altdisreolution/ comments/barsamian.htm (last visited Mar. 9, 2002) (comments of Anthony Barsamian).

291 http://www.cybersettle.com/faq (last visited Mar. 9, 2002).

${ }^{292}$ http://www.ecodir.org/odrp/details.htm (last visited Mar. 9, 2002).

${ }^{293} \mathrm{Id}$.

${ }^{294}$ See http://www.i-courthouse.com/main.taf (last visited Mar. 9, 2002).

${ }^{295}$ Seehttp://www.i-courthouse.com/main.taf?areal_ad=about\&area2_id=faqs (last visited Mar. 9, 2002).

${ }_{296}$ See http://www.intellicourt.com/about_us.html (last visited Mar. 9, 2002).
} 
- IleveL: this mediation site permits both parties a finite time frame to craft a solution; as an added incentive to reach settlement, the site has created a Court of Public Opinion where failed reconciliation efforts are posted to a community repository. ${ }^{297}$

- InternetNeutral: this mediation site started in 1997 to "offer mediation services to resolve disputes between Internet businesses and their customers or suppliers." 298 The mediations are nonbinding. ${ }^{299}$ According to the site, "mediation results in settlement $85 \%$ of the time." ${ }^{\prime 30}$ There is a nonrefundable fee of $\$ 250$ for two hours of mediation session time plus two hours for reading and preparation by the mediator, with additional fees for any additional time. $^{301}$

- Mediation American: this site custom designs Web Based Mediation Portals for clients seeking to engage in their own dispute resolution or multi-purpose video conferencing. ${ }^{302}$

- Mediation Arbitration Resolution Services (MARS): this mediation and arbitration site is "dedicated to providing an accessible and exceptional dispute resolution process." The site handles all kinds of cases through its Super Settle ADR program with blind bidding to reach a numerical settlement and its Fair \& Square ADR program involving a mediator. ${ }^{303}$

- Onlinemediators: this mediation site started January 2000, offering online mediation for all kinds of disputes. ${ }^{304}$ The parties determine whether the outcome will be binding. ${ }^{305}$ The site is linked with onlineresolution.com, which offers online negotiation, online mediation, online expert evaluation, and online arbitration. ${ }^{306}$

- Online Ombuds Office: this mediation site started in June 1996, to provide online mediation services through ombudsmen for

\footnotetext{
See http://www.ilevel.com last visited Mar. 9, 2002).

ICC Intenton, supra note 270 , at 21.

Id. at 22.

3ik http://www.internetneutral.com/nutshell.htm (last visited Mar. 9, 2002).

:3is See http://www.internetneutral.com/fees.htm (last visited Mar. 9, 2002).

$31:=$ See http://www.mediationamerica.com/services/index.asp (last visited Mar. 9, 2002).

30.3 http://www.resolvemydispute.com/mstmt.htm (last visited Mar. 9, 2002).

:3it See ICC Inventory, supra note 270 , at 28.

315 Id at 30.

:He; See http://www.onlineresolution.com/services.cfm (last visited Mar. 9, 2002).
} 
disputes arising from any kind of online activity. ${ }^{307}$ Ombudsmen are independent officials who receive complaints, investigate complaints, and make recommendations. ${ }^{308}$ The site is the dispute resolution arm of the Center for Information Technology and Dispute Resolution at the University of Massachusetts. ${ }^{309}$ The ombudsperson does not make a final decision on the dispute; rather, the outcome of the mediation is a settlement agreement between the parties. The enforceability of the settlement agreement is up to the parties. ${ }^{310}$

- National Arbitration Forum: this site offers arbitration, mediation, and dispute resolution for domain name disputes and other types of cases. ${ }^{311}$ Unless the parties specify otherwise, all arbitration awards are final and binding. ${ }^{312}$

- Resolution Forum: this mediation and arbitration site provides a conferencing system for the mediation and arbitration processes for all business-related disputes. ${ }^{313}$ The mission of this non-profit educational organization is to "improve the quality and efficiency of dispute resolution services." "314 Resolution Forum, Inc. works in close association with the Center for Legal Responsibility at South Texas College of Law. ${ }^{315}$

- ResolveItNow.com: this negotiation site was developed by a California Superior Court Settlement Judge and a leading ADR lawyer, expert, and consultant. The site uses blind bidding and charges $\$ 150$ per party for settlements at $\$ 3,000$ or more; for settlements less than $\$ 3,000$, the parties pay five percent of the settlement amount. ${ }^{316}$

- Settlementonline.com: this negotiation site seeks "to improve traditional methods of resolving disputes by integrating the Internet

\footnotetext{
307 See ICC Inventory, supra note 270 , at 31 .

${ }^{308}$ See Katsh, supra note 225, at 966.

${ }^{309}$ See Center for Information Technology and Dispute Resolution, 1, available at http://www.ombuds.org/center/ombuds.html (last visited Mar. 9, 2002).

${ }^{310}$ See ICC Inventory, supra note 270 , at 32.

311 See $i d$. at 45.

${ }^{312}$ Id. at 49; see also http://www.arbforum.com/about/questions/asp (last visited Mar. 9, 2002).

${ }^{313}$ See ICC Inventory, supra note 270 , at 33.

${ }_{314}$ http://www.resolutionforum.org (last visited Mar. 9, 2002).

${ }^{315}$ Id .

${ }^{316}$ See http://www.resolveitnow.com (last visited Mar. 9, 2002).
} 
and related interactive services into the process." "317

- Settleonline: this negotiation site offers an "online computer assisted method for settling disputes by giving its users the power to negotiate with total confidentiality."318 ADR services are provided by Resolute Systems Inc. ${ }^{319}$

- Settlesmart: this site offers online confidential settlement processes for disputes and lawsuits. ${ }^{320}$

- SquareTrade: this mediation site was started in the fall of 1999 to provide mediation in e-commerce transaction disputes. ${ }^{321}$ The site handles disputes involving "non-delivery of goods or services, misrepresentation, improper selling practices, un-honored guarantees or warranties, unsatisfactory services, credit and billing problems, unfulfilled contracts, etc." 322 Unless agreed upon by the parties, the mediation is not binding. ${ }^{323}$

- The Claim Room: this negotiation and mediation site uses blind bidding and confidential communication areas for text-based negotiations; the site is designed to be used in support of traditional "open" negotiations. ${ }^{324}$

- USSettle.com: this site started in April 1999 to offer ADR services to settle financial disputes through Web-based technology. ${ }^{325}$ The site also provides mediators if the dispute does not settle through the Web-based technology. ${ }^{326}$

- Virtual Magistrate (VMAG): this free arbitration site started on October 25, 1995, to resolve disputes among online computer users, computer operations, and those harmed by the posting of wrongful online messages. ${ }^{327}$ VMAG started as a pilot project funded by the National Center for Automated Information

\footnotetext{
17 http://www.settlementonline.com (last visited Mar. 9, 2002).

${ }^{318}$ ICC Inventory, supra note 270 , at 39.

31! See http://www.settleonline.com (last visited Mar. 9, 2002).

321 See http://www.settlesmart.com/how.htm (last visited Mar. 9, 2002).

"321 See ICC Inventory, supra note 270 , at 42.

3's See http://www.squaretrade.com/cnt/jsp/hlp/help_odr_case_file.jsp; jsessionid=vh3pwa70d2: whost (last visited Mar. 9, 2002).

${ }^{3}{ }^{\prime}$ Id. at 43 ; see also http://www.squaretrade.com/cnt/jsp/hlp/help_odr_case.jsp; jsessionid=vh3pwa70d2?vhostid=t (last visited Mar. 9, 2002).

${ }^{324}$ http://www.theclaimroom.com/visitors.html (last visited Mar. 9, 2002).

325 See http://www.ussettle.com/howworks.htm (last visited Mar. 9, 2002).

334 Id.

${ }_{3 ! 7}$ See http://www.vmag.org (last visited Mar. 9, 2002).
} 
Research and the Fellows of the Cyberspace Law Institute. ${ }^{328}$ The site is now run by the Chicago-Kent College of Law. ${ }^{329}$

- WeGanSettle.com: this site uses "independent, neutral and secure technology to compare offers from both sides and declares a settlement when the figures are close enough." 330

- WebMediate: this site offers resolution services for online transactions and insurance claims. Neutral mediators facilitate discussions and negotiations between the parties, helping them towards a solution. ${ }^{331}$ The site also offers arbitration services. ${ }^{332}$

${ }^{328}$ See Vittual Magistrate Established for the Internet, at http://www.eff.org/Legal/Arbitration/ virtual_magistrate.announce (Mar. 4, 1996).

329 See http://www.vmag.org/docs/FAQ.html (last visited Mar. 9, 2002).

${ }^{330} \mathrm{http}: / /$ www.wecansettle.com/pages/welcome.html (last visited Mar. 9, 2002).

${ }^{331}$ See http://www.webmediate.com/faq.html (last visited Mar. 9, 2002).

${ }^{332}$ Id. 